\title{
Musicus et poeta trilinguis. New Findings about the Life and Work of Jirí Cropatius Teplický
}

\section{Marta Vaculínová - Petr Daněk}

Abstract: This joint article by a classical philologist and a musicologist deals with Jiří Cropatius (a figure documented between 1569 and 1580). Until now, he has been known as a composer who achieved what no other Czech had ever done: getting his music printed by Angelo Gardano in Venice. Current research on sources has allowed us to expand greatly our knowledge about Cropatius's life. In light of new discoveries, Cropatius is now seen as not only a musician, but also an expert on Latin, Greek, and Hebrew, the languages in which he also wrote poetry. We learn more about his life and, in particular, about his journey to the Holy Land. Cropatius's Masses, issued in print by Gardano in 1578 , have not been preserved, but we can get an idea of what kind of composer Cropatius was from two preserved voices from a manuscript of his Mass for five voices now kept at the Staatsbibliothek zu Berlin.

Key words: Printed music, polyphonic settings of the Ordinary, journey to the Holy Land, humanism in music, part books, conversion, Jiří Cropatius, Angelo Gardano

It is noteworthy how often in the literature dealing with musical culture in Bohemia or the history of European music printing, the name Jiři Cropatius is mentioned (he wrote his own name as Georgius Cropatius or Cropacius, but he is also known from sources and the literature as Georg Kropácz, Kropácž, Jorgius Cropatius, and Jurge, and his name has even been misspelled as Coppacius, Cropalius, or Giorgio Cropalio ${ }^{1}$ ). The frequency with which the name is cited is peculiar given that so far very little is actually known about his life or work. Jiří Cropatius is remembered primarily because in 1578 in Venice he had the title Missarum tomus primus quinque vocum iuxta dodecachordi modos, dorii scilicet, hypodorii et lydii accurate compositus, recensque in luce editus published by Angelo Gardano, a leading

1) For example, as Georgius Cropalius, composer of a five-voice Mass published in Venice in 1578, he appears in the revised universal bibliography: Bibliotheca instituta et collecta primum per Conradum Gessnerum ... deinde locupletata ... cum priorum tum novorum authorum opusculis, ex instructissima Vienensi Austriae Imperatoria Bibliotheca amplificata, per Iohannem Iacobum Frisium Tigurinum, Tiguri: Christophorus Froschauer 1583, p. 267. To the bibliography revised in 1574 by Iosias Simler, Jakob Frisius added older and new titles from the Imperial Court Library in Vienna. One would then assume that Cropatius's printed music was there at the time. 
European printer specialising in music. To this day, no preserved printed specimen has been found, but the mere fact that a composer from a family of Protestant townsmen who was trying to gain a foothold in the environment of Bohemian cities (Teplice, Louny, Rokycany, Prague) had a collection of polyphonic Mass settings published by a Venetian printer in the late 1570 s is so historically extraordinary and unique that it has been inspiring more in-depth consideration and study for several years.

\section{The origins of Jiři Cropatius, his studies, and his activities in Bohemia}

Until now, information about the origins, life, and activities of Jiří Cropatius ${ }^{2}$ has mainly been derived from a handful of prints of his occasional poetry published in 1574-1575 by the printing presses of Jiří Nigrin and Jiří Jakubův Dačický in Prague. Now, however, we have discovered more details, which have significantly expanded his still sketchy biography.

Cropatius was born in ca. 1550 in Teplice (Teplicenus, Teplicensis) to a non-Catholic family. We know nothing concrete about how his studies began. He himself writes that he was interested in languages from his youth, having shown an affinity for not only Latin and Greek, but also Hebrew, with which he may have become familiar among members of Teplice's sizeable Jewish community, ${ }^{3}$ or more likely later while studying in Wittenberg. In his prints, he also used Czech occasionally, and one would assume that he also knew German and Italian. In the foreword to one of his prints, Cropatius says the following about the knowledge of languages:

"The study of languages is not merely useful; rather, it also brings noble pleasure to the mind, when those who read Hebrew can draw the living voice of God directly from the source, and when they get to know the good authors in Greek and Latin in the languages in which they themselves spoke during their lifetimes. Once I myself had begun to understand this useful and pleasant aspect of the knowledge of languages, already as a boy I set to work in order to master at least a small amount of this vast, sublime material in such a way that it would rightfully belong to me, so to speak."

Cropatius undoubtedly gained a deeper knowledge of the three holy languages at the university in Wittenberg, where he matriculated on 4 December 1569 as Georgius Cropacius

2) For a brief discussion of his life and works, see TRUHLÁŘ, Josef - HRDINA, Karel - HEJNIC, Josef MARTÍNEK, Jan: Rukovět' humanistického básnictví v Čechách a na Moravě 1 (A Handbook of Humanistic Poetry Written in Bohemia and Moravia, hereinafter Rukovět), Academia, Praha 1966, pp. 496-497.

3) There are records of a Jewish school in Teplice in 1554, and the population of the Jewish community was gradually increasing; see BURGEROVÁ, Lenka - SPÁLA, Radek: Židé v Teplicích - 600 let historie (Jews in Teplice - 600 Years of History), Jan Zykmund, Teplice 2014, p. 8.

4) In the foreword to Carmen ad filium Dei, Pragae: Georgius Nigrinus 1575, Alb: "Neque vero utile tantum est hoc linguarum studium: sed etiam liberalem animis voluptatem affert: dum vivam DEI vocem in sanctis scripturis haurire videntur ii, qui hebraea legunt: et bonos autores, Graecos et Latinos cognoscunt in ea lingua, qua ipsi, cum viverent, sunt locuti. Hanc ergo cognitionis linguarum utilitatem et suavitatem, cum ego quoque intelligere caepissem: statim a pueritia in hanc curam studiose incubui, ut magnae et honestae rei quantulamcunque partem propriam mihi facerem, et meo quasi iure possiderem." 
Vandalus. ${ }^{5}$ He probably remained there until early 1574, when he was still an author contributing to prints with the Wittenberg impressum. ${ }^{6}$ He then departed for Prague, where he was active as an author from 1574 to 1575 . Of the intellectuals there, the one closest to him was the already respected editor and poet Tomáš Mitis. Mitis had visited the baths in Teplice, ${ }^{7}$ so he may have already met Cropatius at the latter's birthplace.

At first, Cropatius served as the preceptor of Balthasar, the son of Jiři Mehl of Střelice, vice-chancellor of the Kingdom of Bohemia. Jiří Mehl, a Protestant nobleman from Breslau who spent considerable sums on his own personal presentation, was known as a patron of the arts and a bibliophile, and his Renaissance renovation of Grabštejn Castle is also noteworthy. ${ }^{8}$ Nothing, however, is known about his interest in music apart from a mention in a foreword dedicated to him by Jiř́ Cropatius. It is also from the foreword that we first learn about Cropatius's activities as a composer. At the same time as the poem De adventu Iesu Christi, he also gave Mehl an Officium Missae for five voices composed on the basis of a motet:

"To this negligible gift I have also attached an Officium Missae, which I recently composed for five voices on a motif from a motet, because interest in poetry goes together excellently with interest in music, and you love one no less than the other. I therefore implore you again and again that you might receive both little gifts, however modest and insignificant they may be, with loving kindness, and that you do not cease to help and support me. Later, when the right time comes and the Muses show me more favour, I shall attempt to submit to you something more serious and greater. And it would be the greatest challenge to me, were I to sense that you have accepted this clumsy work with a favourable turn of mind."

5) Album academiae Vitebergensis, Vol. 2: Ab a. ch. MDII usque ad a. MDCII, Niemeyer, Halle 1894, p. 172. He was enrolled free of charge among those who were "gratis inscripti". In those days, the meaning of the designation "Vandalus" was broad, and it could have referred to inhabitants of the Baltics, Pomerania, Russia, Prussia, Poland, and neighbouring countries, but here it is probably means "Slav".

6) Specifically, he contributed to Felix Chrudimský's printing Historia passionis (Rukovět' 2, pp. 135-136; Verzeichnis der im deutschen Sprachbereich erschienenen Drucke des 16. Jahrhunderts [hereinafter VD16] ZV 18634) and also to three other occasional printings of Czech students at Wittenberg; for a listing, see Rukovèt' 1, p. 497.

7) However, his Ode de thermis Teplicensibus predates 1561; see Rukovět' 3 , p. 359.

8) See ŠŤOVÍČEK, Jan: Renesanční bibliofil Jiř́ Mehl ze Střelic (The Renaissance Bibliophile Jiří Mehl of Střelice), Fontes Nissae, no. VI, 2005, pp. 6-23. For information about Mehl as a dedicatee, see STEINMANN, Marc: Der Libellus gnomologicus des Joachim Camerarius (1569): Bemerkungen zur Entstehungs- und Textgeschichte sowie zur pädagogischen Intention, in: Camerarius Polyhistor: Wissensvermittlung im deutschen Humanismus, ed. Thomas Baier, Narr Francke Attempto, Tübingen 2017, pp. 95-97. Concerning the reconstruction of Grabštejn, see WINZELER, Marius: Kaple sv. Barbory na hradě a zámku Grabštejn (St Barbara's Chapel at the Grabštejn Castle and Chateau), online: http://www.mikroreg.info/index.aspx?rub=112 (there is also older literature here).

9)Foreword to Ode de adventuIesu Christi, Pragae: Georgius Daczicenus 1574, alb (wewish tothankLenka Veselá for the copy of the print): "Huic exiguo munusculo adiunxi etiam officium Missae: quod symphonia 5 vocum, super quandam mutetam nuper composui: siquidem et poetica studia cum musicis optime coniunguntur: et tu non minus haec, quam illa, amas. Quare obnixe etiam atque etiam oro: ut utrumque munusculum, exiguum licet, ac levidense, grato benevoloque animo suscipere velis: et me iuvare et promovere non desistas. Alio tempore, dum maturuerit aetas: et si Musae magis favebunt meis coeptis: graviora, melioraque offerre conabor. Ad quae plurimum me excitabis: cum intellexero grato haec parta et rudia te accepisse animo." 
We do not know for how long Cropatius was in Mehl's services. On the basis of the dedications of prints, it seems that not long after having written this foreword, he was seeking a new position - in a succession of occasional prints, he approached the town councils of Rokycany, Louny, and Prague's Old Town and New Town. ${ }^{10}$ He seems not to have found work in Bohemia, however, and he vanishes without a trace until 1578, when he reappears on a journey to the Holy Land.

\section{Cropatius in Italy and on a journey to the Holy Land}

Cropatius travelled to Jerusalem from Padua, where he may have studied with Hans von Arnim, who was also a participant in the expedition. ${ }^{11}$ Philipp Han drew heavily from Hans von Arnim's detailed travel diaries for the sermon at the latter's funeral. ${ }^{12}$ On the way, in Venice Cropatius had Antonio Gardano print a set of five-part musical settings of the ordinary of the Mass, the full title of which is known, but there are no know preserved specimens. There may be one piece of literary evidence supporting the assertion that Cropatius spent time in Padua. In a manuscript of the important Italian humanist Bernardino Baldi of Urbino

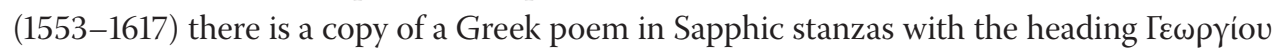

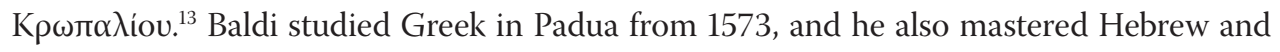
Chaldean. Possibly (although it cannot be said with certainty) it was at the time of his studies in Padua that he met Cropatius and obtained his poem. Baldi placed it in the part of his manuscript that was a compilation of Greek and Italian poems dedicated to Gioseffo Zarlino, ${ }^{14}$ an important Italian composer and music theorist, who will be mentioned later in our text in connection with Cropatius's printed masses (AD IOSEPHUM ZARLINUM CARMINA). ${ }^{15}$ Cropatius's Greek poem in Baldi's manuscript collection is in the style of the humanistic odes, and it celebrates music as a great, divine gift. It deals with music's beneficial effects on people, and it praises Zarlino's contribution to music and singers.

We have reports about Cropatius's journey to Jerusalem from the preserved travel diaries of the aristocratic adventurers, mercenaries, and travellers Leopold von Wedel (1544-1615) and Jost Fögelli (1554-1607), both of whom mention the Bohemian student and musician. ${ }^{16}$

10) For a list of these prints, see Rukovét' 1 , pp. 496-497.

11) His itinerary is described only very briefly in GRUNDMANN, Christian Wilhelm:Versuch einerUcker-Märckischen Adels-Historie, Bd. 1, Christian Ragoczy, Prentzlau 1744, pp. 183-184.

12) Christliche Betrachtung aller Gottes Heiligen und Gleubigen Pilgram- und Bürgerschafft. (Herzog August Bibliothek Wolfenbüttel, shelf mark Xa 1:1 [12], hereinafter HAB). See BEPLER, Jill: Travelling and Posterity: the Archive, the Library and the Cabinet, in: Grand Tour: Adeliges Reisen und Europäische Kultur vom 14. bis zum 18. Jahrhundert, Jan Thorbecke Verlag, Ostfildern 2005, p. 201.

13) BRAVI, Luigi: Epigrammi greci in un manoscritto di epigrammi di Bernardino Baldi, Studi umanistici Piceni, vol. 36, 2016, pp. 205-206 (edition with an Italian translation, hereinafter BRAVI). The editor of the poem comments that he was unable to find any details about the identity of the author.

14) B. Baldi is also the author of the first biography of Gioseppe Zarlino. Cf. BALDI, Bernardino: Le vite de' matematici: Edizione annotata e commentata della parte medievale e rinascimentale a cura di E. Nenci, F. Angeli, Roma 1998, pp. 543-557.

15) BRAVI, op. cit. in footnote no. 13, pp. 200-201, 204-206.

16) Wedel's description was published by BÄR, Max: Lupold von Wedel's Beschreibung, F. Hessenland, Stettin 1895 (hereinafter $B \ddot{A} R$ ), and there is a newer, detailed discussion with an overview of older literature in 
He probably joined the expedition in May 1578 in Venice together with Hans von Arnim, with whom he may have studied in Padua earlier, and with Jost Fögelli. ${ }^{17}$ Another member of the expedition was the Dutch physician Bernardus Paludanus (1550-1633), whose preserved album contains entries also documenting the progress of the journey. ${ }^{18}$ From Venice (where Cropatius had Masses printed, as is discussed below), the travellers sailed for Cyprus on 22 June 1578, then they passed through Tripoli and proceeded to Jaffa, where they landed on 4 August. Joining the expedition in Ramla was Kryštof of Fictum, later the director and a member of the Defenders of the Faith during the Estates Revolt. ${ }^{19}$ Forty-eight days after sailing from Venice, the travellers arrived in Jerusalem on 8 August 1578. There, they spent a week visiting holy sites, including the usual programme for visitors and pilgrims. ${ }^{20}$ The group then divided, and the noblemen and their guides continued on their journey, while Cropatius and three Jesuits split off from the expedition on 15/16 August. Cropatius stayed behind in Jerusalem in order to devote himself to music and to compose something for the monks at St. Saviour's Monastery. ${ }^{21}$

In the travellers' reports from Jerusalem, Cropatius is spoken of as a Catholic who did not refuse to go to confession at the Franciscan church together with Fögelli and Hans Sebald von Gemmingen. The other members of the expedition, who were Lutherans, did not wish to go to confession, of course. ${ }^{22}$ One may assume that during his stay in Italy, Cropatius was converted. In Jerusalem he met Meletius Pegas, later the Patriarch of Alexandria. In his Latin poem, Meletius praised Cropatius as an outstanding musician and an expert on languages. ${ }^{23}$

KOŚCIELNA, Joanna A.: Lupolds von Wedel Bericht von der Reise in den Nahen Osten (1578-1579). Teil I: Peregrinatio Hierosolymitana Leopoldi de Wedell, Stargardia, vol. X, 2015, pp. 233-279 (hereinafter KOŚCIELNA). Concerning Cropatius p. 243, footnote no. 84 and pp. 254-255. Fögelli's description of the journey, preserved in Fribourg, was described by von DIESBACH, Max: Le pellegrinage en Terre-Sainte de Josse Voegeli 1578, Revue del histoire vaudoise, vol. 9, 1901 (hereinafter DIESBACH). An expanded description with illustrations has been published by KING, Norbert: Die „Pilgerfartt" des Freiburger Ritters Josef Fögelli (1578-1579), Freiburger Geschichtsblätter, vol. 86, 2009, pp. 117-186 (hereinafter KING).

17) BÄR, op. cit. in footnote no. 16, p. 62: "Zudem ist da ein Studente aus dem Lant zu Bemen, welcher auch zu Padua studeret, mit dem Dofnam Jurge genannt, der Zunam mir vorgessen. Derfultig handelt auch, dass er mit zok (1578, Mai, Juni)."

18) Nationale Bibliotheek van Nederland, Den Haag, shelf mark KW 133 M 63; for general information, see KOŚCIELNA, op. cit. in footnote no. 16, p. 237 et passim, which draws attention to specific entries.

19) Mezi houfy lotrův se pustili... České cestopisy o Egyptě 15.-17. století (To Set Out among Hoards of Thieves. Czech Travel Books about Egypt of the $15^{\text {th }}-17^{\text {th }}$ Centuries), ed. Lucie Storchová, SET OUT- Roman Míšek, Praha 2005, pp. 224-227 (letter by Kryštof Fictum from Aleppo).

20) KING, op. cit. in footnote no. 16, pp. 128-129.

21) KING, op. cit. in footnote no. 16, p. 131: "vnnd liessen do die dry Jesuiter vnnd vnsser Gsellen ein, Jorgius Cropatius genannt, ein Böhem, welcher sagt, er welle ein monat oder etlich do blyben, dan er was ein Componist oder Musicus unnd wolt den Brüdren (des Salvatorklosters in Jerusalem) etwas machen" (fol. 86v). Twenty years later, in 1598, Kryštof Harant of Polžice and Bezdružice also stayed at St. Saviour's Monastery. He was captivated by the singing of the monks, which inspired him to create a motet based on Psalm 124; see HARANT z POLŽIC a BEZDRUŽIC, Kryštof: Putováni aneb Cesta z království českého (Wandering, or A Journey from the Kingdom of Bohemia), ed. Hana Bočková et al., Host, Praha - Brno 2017, p. 166 ff. and 294.

22) KOŚCIELNA, op. cit. in footnote no. 16, p. 255.

23) Published from a manuscript in the library of the Greek specialist Ioannes Sakkélion by Émile LEGRAND: Lettres de Mélétius Pigas, J. Maisonneuve, Paris 1902, p. 8; on p. IX of the foreword, he also refers to its 
His poetic praise has been preserved in two manuscript versions in the context of other texts commemorating Meletius's stay in Jerusalem, ${ }^{24}$ where he had arrived in 1579 in the entourage of Archbishop Eugenius of Sinai for the election of Patriarch Sophronius IV. The heading of the poem, which has been preserved in Ioannes Sakkélion's manuscript, mentions Cropatius's main qualities, namely as a musician and an expert on three holy languages:

\section{Ad Georgium Copaccium (!) Polacum apprime doctum triplicique in genere linguarum versatissimum, tum musicum ac poetam peritissimum. ${ }^{25}$}

Non tu pectus iners sine numine docte Georgi

Calliopes, Euterpes, Uraniesque decus.

Carmine tu, numerisque potens, ${ }^{26}$ non saeva ferarum

Pectora, sed poteris flectere corda hominum;

Corda hominum, superumque ${ }^{27}$ tibi Threicius' $O \rho \phi \varepsilon u ́ s$

cedat, seque matre iam neget esse Dea. ${ }^{28}$

Other reports on Cropatius's fate are uncertain. It is questionable whether we can identify him as the alumnus of the Olomouc college, 30 years old at the time (on the basis of this report, if this really was "our" Cropatius, we would be able to estimate that he was born in ca. 1550), who was thrown out of the college "propter liberius ingenium" on 20 May 1580, and who asked to be allowed to return to the seminary. We know that Cropatius had already converted earlier, and that in the Holy Land he was in contact with Jesuits, so it cannot be ruled out that he might have entered the Olomouc seminary. His case was handled leniently because he had converted a certain non-Catholic lady to the faith and because after his own conversion, his Protestant parents had refused to support him, so accommodations were secured for him with one of the townsmen of Olomouc, and he received a small amount of financial support, but he was not allowed to return to the seminary. ${ }^{29}$

occurrence in a manuscript of the university in Tübingen, shelf mark Mb 10, p. 332 with the heading "Ad Georgium Cropacium Polacum poetam et musicum". This manuscript, known as the "Le codex Vratislav", was in the possession of a professor of Greek named Martin Crusius, who furnished the texts with Latin marginalia, and in the case of our poem, we read "Laus poetae".

24) E.g. the poem of the Jerusalem guardian Jeremias von Brixen on p. 330 of the Tübingen Manuscript.

25) Ad Georgium Cropacium Polacum poetam et musicum] Tübingen Manuscript.

26) potest] Tübingen Manuscript.

27) supernumque] Tübingen Manuscript.

28) The reproduced text is based on Legrand's edition of Sakkélion's manuscript, and the variant readings in the footnotes are from Martin Crusius's Tübingen Manuscript (see footnote no. 23).

29) THENIER, Augustin: Versuche und Bemühungen des heiligen Stuhles in den letzten drei Jahrhunderten die durch Ketzerei ... von ihm getrennten Länder des Nordens wieder mit der Kirche zu vereinen, Verlag der Karl Kollmann'schen Buchhandlung, Augsburg 1839, vols. 1-2, p. 137 quotes a letter from the papal legate Antonio Possevino dated November 1580 from Prague: "Georgius Cropacius, Bohemus, 30, discessit 20 Maji 1580 ... Georgius autem Cropacius, nobilis Bohemus, cum propter liberius illius ingenium dimissus esset, ac vero me redeunte vehementer ursisset, ut iterum admitteretur in Seminarium, existimatum est, ut neque reciperetur, nec tamen omni praesidio destitutus relinqueretur, quod ob nobilitatem, et quia nobilem matronam Picardicam convertit, quodque ejus parentes haeretici nihil illi suppeditant, adjuvandus videretur. Itaque ad duos menses pensionem ei solvi apud civem Olomucensem unius talleri cum dimidio pro singulo mense, pecuniamque Patri 


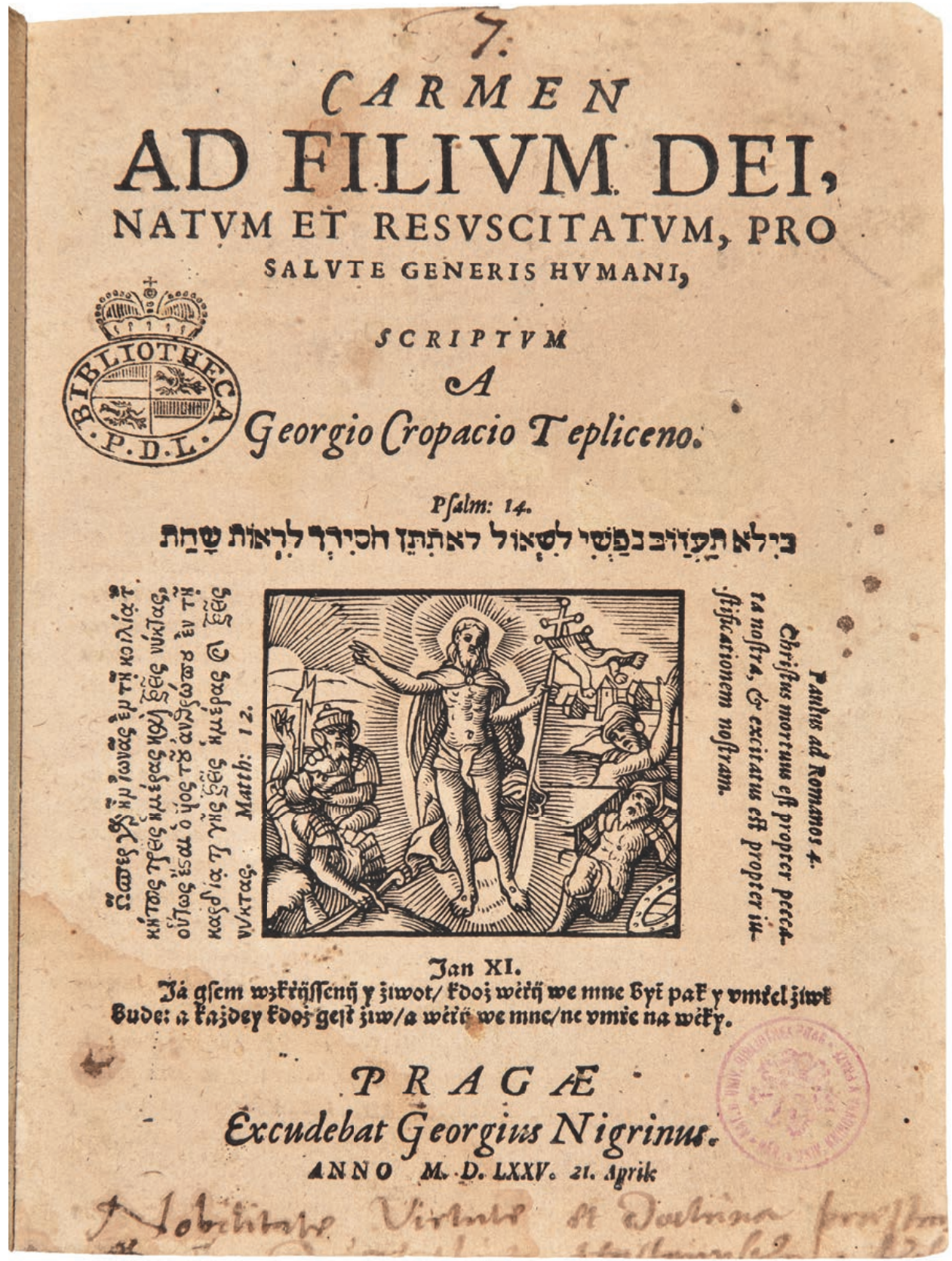

Jiří Cropatius: Carmen ad filium Dei natum et resuscitatum...

Print / Tisk, Jiř́ Nigrin, Praha, 1575

Title page / Titulní list

National Library in Prague, shelf mark 65 E 1925 / Národní knihovna Praha, sign. 65 E 1925 
According to Bohuslav Balbín, Cropatius continued his literary activities, supposedly still publishing his poems in 1580, 1583, and $1585 .{ }^{30}$ Balbín's assertion, taken up later by Cerroni as well, ${ }^{31}$ can be neither confirmed nor refuted; today, we do not have any of the printed materials that were published under his name at the time.

\section{Cropatius as a poet}

In literature, Cropatius profiled himself as a poet. Besides standard Latin, he also wrote in Greek from his student days, and he is also important as the only Bohemian humanist of the period before the Thirty Years' War to have printed his own poetry written in Hebrew. His preserved poetic works belong to the genres of occasional and religious poetry. As far as his works in Latin are concerned, we can speak of good craftsmanship in his mastery of verse technique and the basic rules of the genres, while he used practically only two verse forms the elegiac couplet and the Sapphic stanza. Cropatius's verses in Greek and Hebrew have yet to be evaluated. Both of these languages appear in prints, but Greek was often prioritised, and the poet was also recognised abroad for his knowledge of Greek, as is shown by one poem preserved in manuscript.

Cropatius's verses were first printed in Wittenberg after about two years of study in 1571. He wrote a brief poem in Greek and Latin versions to accompany Jan Felix Chrudimskýs religious epic Historia Passionis. Here, contrary to usual practice, the Greek version is primary, and a Latin paraphrase follows it. After a silence of some length, at the beginning of 1574 Cropatius contributed to an anthology of epicedia for the wife of Ernst Albrecht Kindler von Zackenstein, with whose sons he was studying in Wittenberg. Other Bohemian humanists contributed to the anthology - Tomáš Mitis, Šimon Proxenus, and Jakub Havlík of Varvažov. Here, too, Cropatius presents the poem first in Greek and then in Latin. It is relatively lengthy, with 31 elegiac couplets.

After returning to Bohemia, that same year Cropatius contributed to two more prints published by Jiří Nigrin (where more than half of the poems being produced were published at the time), ${ }^{32}$ contributing epithalamia in Sapphic stanzas to an anthology for Kašpar Menšík of Menštejn and Václav Havlík of Varvažov. While the epithalamium for Menšík is quite conventional, in the epithalamium for Havlík of Varvažov, the author allows three virtues associated with marriage - piety, concord, and patience (Pietas, Concordia, Patientia) to speak in succession. It cannot be ruled out that their speeches were to have been set to music.

During his Prague period, confined to the years 1574-1575, Cropatius had several separate small prints and broadsheets published. Their common denominator with a single exception

Rectori Collegii reliqui, qua si vel is vel aliquis alius pergant in studiis et pietate, possint tantisper juvari, dum cum V. D. Ill[ustrissi]ma loqui potero."

30) BALBÍN, Bohuslav: Bohemia docta, Pars I., ed. K. R. Ungar, Pragae: Adamus Hagen 1776, p. 278.

31) See Rukovět' 1, p. 497.

32) ŠÍCHA, Vojtěch: Jazyková skladba pražské tiskařské produkce 16. století (The Linguistic Content of Prints Produced in Prague in the $16^{\text {th }}$ Century), Knihy a dejjiny, vol. 25, 2018, nos. 1-2, p. 58. 
is poetry with religious content, which he dedicated to his patrons and to influential townsmen or city council members, from whom support could be expected.

Probably Cropatius's oldest Prague print is Ode de adventu Iesu Christi for Jiř́ Mehl of Střelice, which he had printed by Jiří Jakubův Dačický. He entrusted all of his later printing to Jiř́ Nigrin. According to the foreword, Cropatius began writing the ode at Christmas in 1573 (this type of poetry was a usual Christmas or New Year's gift in those days), but he did not have it published until 1574. The short Hebrew poem "in Cristum Emmanuelem" is printed on the title page, followed by a Latin poem on the arrival of Christ with a length of thirty-six Sapphic stanzas.

The aforementioned exception, worthy of special attention, is a broadsheet with an epicedium by Jan Vartovský of Varta ${ }^{33}$ in three languages. For the first time, Cropatius adds Hebrew to the Latin and Greek. While printers in the Czech lands had been using Greek typeface since the 1550s, Cropatius's broadsheet from Jiří Nigrin's printing press happens to be the first documented use of Hebrew type in this country. ${ }^{34}$ In the broadsheet, besides knowledge of languages, the author also demonstrates formal poetic skill - all three language versions contain the name of the departed as an acrostic. Jan Vartovský of Varta died on 3 July 1559, so the broadsheet may have been published for the fifteenth anniversary of his death. In view of the fact that an epicedium was usually published not long after the death of the person in question, one may wonder what led Cropatius, who was still just a boy when Vartovský died, to the delayed publication of an epicedium. We learn nothing more from Vartovskýs epitaph by Tomáš Mitis, which is also printed on a broadsheet. We may assume that Cropatius wished to lay claim to the legacy of Jan Vartovský of Varta as a learned man who had mastered three holy languages and translated from them into Czech. The epicedium begins with a reflection on the brevity of human life, which sometimes ends suddenly, as was the case with Vartovský. At the heart of the poem is praise of his knowledge of Hebrew, Greek, and Latin, and at the conclusion Cropatius predicts not only Vartovskýs eternal life, but also eternal fame. Perhaps the broadsheet, endorsed by Mitis's authority, was intended by its author as a kind of recommendation for Jan Vartovskýs son, who shared his father's name and inherited his (surely interesting) library including the manuscripts of his translations. ${ }^{35}$

Cropatius's Wittenberg education is clearly seen from the choice of subjects and forms. That education also left its mark on the older generation of Czech humanists, likewise

33) Jan Vartovský of Varta was a gifted Prague townsman who translated the Old Testament from Hebrew. The manuscript has not been preserved, however; see VOIT, Petr: Starý Zákon [encyclopaedia entry for "Old Testament"], in: Encyklopedie knihy (The Book Encyclopaedia), Libri, Praha 2006, p. 840. As late as 1566, some scholars were attempting to publish the translation, being urged by Jan Blahoslav to do so quickly JIREČEK, Josef: Rukovět' k dějinám literatury české do konce XVIII. věku: ve spůsobě slovnika životopisného a knihoslovného (A Manual on the History of Czech Literature to the End of the $18^{\text {th }}$ Century: in the Manner of a Biographical and Bibliographical Dictionary), B. Tempský, Praha 1875, p. 310.

34) VESELÁ, Lenka: Hebrejská typografie v českých nežidovských tiskárnách 16. a 17. století (Hebrew Typography at Non-Jewish Printers of the $16^{\text {th }}$ and $17^{\text {th }}$ Centuries), in: Hebrejský knihtisk v Čechách a na Moravě (Hebrew Book Printing in Bohemia and Moravia), Academia, Praha 2012, pp. 165-176, here p. 169.

35) ADAM z VELESLAVÍNA, Daniel: Kalendár historický (Historical Calendar), Praha: Daniel Adam 1590, p. 303. 
Wittenberg graduates (Matouš Collinus, Tomáš Mitis etc.). ${ }^{36}$ There, religious poetry was very often combined with music. Cropatius's Wittenberg inspiration is seen very concretely in his poetic composition Oda de angelis. It is strongly influenced by an ode with the same title by Philipp Melanchthon, which was set to music many times in the original and in a German translation by Paul Eber. ${ }^{37}$ In some passages, Cropatius uses Melanchthon's original as a framework in which he substitutes words and phrases. This strophe is an example:

Melanchthon:

Interim sed nos tegit Angelorum

Quae ducem Christum sequitur, caterva,

Atque grassantis reprimit cruenta

Arma Draconis.

\section{Cropatius:}

Turma sanctorum vigil Angelorum

Hostis a pravi metuere rictu

Servat et diri reprimit cruenta

Arma Draconis.

Cropatius's poem Cymba Christi may also have had Wittenberg inspiration. In it, the author expands on motifs from the Gospel of Matthew 8:18-21 and describes Christ's church as a ship tossed by a storm. He also explains this motif in the foreword dedicated to the Louny town council. However, if we compare this composition with the poem by Johann Maior with the same title, which is moreover written in elegiac couplet, ${ }^{38}$ we find surprisingly large differences, especially in the use of mythology from antiquity, which is prevalent with Cropatius - on stage, he presents not only Aiolus, keeper of the winds, but also Scylla and Charybdis. At the time, the theme of a ship as a symbol of the church was so widespread that the author may also have had other models in mind, such as the poet Veit Jacobaeus from the university in Vienna, who dedicated hexameters on the same theme to Antonín Brus of Mohelnice on the occasion of the latter's appointment as Archbishop of Prague. ${ }^{39}$

Not even Cropatius himself probably regarded the creation of poetry as his chief attribute, and his poetic attempts must be understood in the context of his oeuvre as little works that served to support his search for a position and to help him make new friends.

36) For more about religious poetry from Wittenberg, see KIPF, Klaus: Geistliche Dichtung Wittenberger Humanisten in der ersten Hälfte des 16. Jahrhunderts - Zeugnis einer Devotionspraxis?, in: Wie fromm waren die Humanisten?, eds. Berndt Hamm - Thomas Kaufmann, Harrassowitz Verlag, Wiesbaden 2016, pp. 261-285.

37) Ibid, pp. 271-273.

38) MAIOR, Johannes: Psalmi duo CXXXI. et CXXV. explicati carmine elegiaco. Item, Cymba Christi, Wittenberg: s. t. 1556, A3a-A5a (VD16 B 3443). Appearing ten years later is the print: BUNTSCHENIUS, Johann: Cymba Christi, quae est imago ecclesiae, Wittenberg: Schwenck 1566 (VD16 B 9785). Specimen HAB A: 36.3 Poet. (35). 39) JACOBAEUS, Vitus - LACTANTIUS CODICIUS, Joannes: Carmen in consecrationem et inaugurationem reverendissimi principis D.D. Antonij de Muglitz, Wien: Hofhalter 1561. Rukovět' 1, pp. 232-233. 
Of note for research on his foreign contacts are occasional poems in manuscript that have been preserved abroad in connection with him, and more may still be found over time.

\section{Cropatius and music}

The printed collection of polyphonic Masses, something quite atypical by Czech standards, that Jiři Cropatius had published in Venice seems to have been first mentioned in a catalogue of the production of Angelo Gardano's printing press from $1591^{40}$ with the following very brief entry: Messe di Georgio Cropatio A 5. et 6. (meaning Masses for five and six voices). ${ }^{41}$ Johann Clessius must have seen the original print; in his listing Unius saeculi, eiusque Virorum litteratorum ... elenchus consummatissimus, he gives the detailed title or a copy of the title page. ${ }^{42}$ Georgius Draudius, ${ }^{43}$ a journalist, publisher, and editor of a series of inventories published at the beginning of the seventeenth century, must have taken this catalogue of prints by Johann Clessius as his point of departure; in one of his pivotal works, Bibliotheca classica sive catalogus officinalis (1625), ${ }^{44}$ he includes Cropatius's work, published according to him in 1548 . This is undoubtedly an error that has been passed on to other literature down to the present day. Cropatius's print is listed in the chapter Libri musici, in the section labelled Missae, where it is cited as: Georg. Cropatii Missarum Tomus primus, 5. vocum, iuxta dodecachordi modos, Dorii scilicet, Hypodorii E Lidii compositus, Venet. 1548. in $4 .{ }^{45}$ It was primarily this work, sometimes corrected to take Clessius into account, which was taken by many encyclopaedists as their point of departure from the eighteenth century until the twentieth. ${ }^{46}$

For example, Johann Gottfried Walther, author of the first German musical encyclopaedia Musicalisches Lexikon oder Musicalische Bibliothec (1732), bases his entry for Jiří Cropatius

40) Cf. AGEE, Richard J.: The Gardano Music Printing Firms, 1569-1611, University of Rochester Press, Rochester 1998, pp. 221, 363, 392, Appendix II. A - Annotation of the 1591 Gardano Booklist a Appendix II. B, Chronological Ordering of the 1591 Gardano Booklist by Date of Publication (hereinafter AGEE).

41) THIBAULT, Geneviève: Deux catalogues de libraires musicaux: Vincenti et Gardane (Venise 1591), Revue de musicologie, vol. 10, 1929, no. 32, pp. 177-183 and vol. 11, 1930, no. 33, pp. 7-18; MISCHIATI, Oscar: Indici, cataloghi e avvisi degli editori e librai musicali italiani dal 1591 al 1798, Olschki, Firenze 1984.

42) CLESSIUS, Johann: Unius saeculi, eiusque Virorum literatorum monumentis ab Anno Dom. 1500 ad 1602, Elenchus consumatissimus, Frankfurt: Ioannes Saurius 1602, p. 396.

43) Draud Georg (1573-1630); Draudius Georgius; Draut Georg; cf. e.g. GREEN, Lawrence D. - MURPHY, James Jerome: Renaissance Rhetoric Short-title Catalogue 1460-1700, Ashgate Publishing, Farnham 2006, p. 171.

44) Cf. DRAUDIUS, Georgius: Bibliotheca classica sive catalogus officinalis in quo singuli singularum facultatum ac professionum libri, qui in quavis fere lingua extant quique intra hominum propemodum memoriam in publicum prodierunt secundum artes et disciplinas ... recensentur, Francofurti ad Moenum: Balthasar Ostern 1625, p. 742.

45) Ibid, p. 1222.

46) The Czech musicology literature of the twentieth century also mentions Jiři Cropatius with the same repeated information about his Venice printing, so it makes no sense to give an overview of it. Among all the titles, we should at least mention Česká polyfonní tvorba. Výbèr vícehlasých děl českého původu z XVI. a XVII. století (Czech Polyphonic Music: A Selection of Polyphonic Works of Czech Origin from the $16^{\text {th }}$ and $17^{\text {th }}$ Centuries), ed. Jitka Snižková, SNKLHU, Praha 1958, p. 14; ŠTĚDROŇ, Bohumír: Cropatius, Jiř́ [entry], in: Československý hudební slovník osob a institucí (Czech Dictionary of Musicians and Musical Institutions), I., SHV, Praha 1963, p. 172; MACEK, Petr: Cropatius, Jiř́ [entry], in: Český hudební slovník osob a institucí (Czech Dictionary of Musicians and Musical Institutions), accessed from:

http://ceskyhudebnislovnik.cz/slovnik/index.php?option=com_mdictionary\&task=record.record_ detail\&id=6345 [accessed on 6 April 2020]. 
on Draudius's work, which he cites directly. He also retains the incorrect dating of Cropatius's print (1548). ${ }^{47}$ On the other hand, nearly a hundred years after Walther, Johann Clessius is referenced by Gottfried Johann Dlabacz (1812), who repeats the information about Cropatius's print and summarises the few existing mentions of him. ${ }^{48}$ The other musical catalogues and dictionaries of the $19^{\text {th }}$ century fail to go beyond Walther or Dlabacz because they lacked new information or discoveries. ${ }^{49}$ It is thus logical that in Volume 5 of the greatest music encyclopaedia of the late nineteenth century, Robert Eitner's Biographisch-Bibliographisches Quellen-Lexikon der Musiker (Leipzig, 1901), it is merely asserted that since the days of Draudius, all encyclopaedias have repeated the same information about Jiří Cropatius. It also states that the constantly referenced edition of Cropatius's Masses had not been found by the publication date of the encyclopaedia. ${ }^{50}$ The entry did not mention that ten years earlier, new information about Jiří Cropatius's works had been discovered in a catalogue being prepared by Emil Bohn, who was working on musical manuscripts from the sixteenth and seventeenth centuries from the collection of the Breslau Municipal Library. Mentioning this information was probably neither possible nor relevant in view of the marginal importance of this entry in Eitner's vast dictionary. In that collection, Bohn had found, amongst other things, one five-voice Mass attributed to Jiří Cropatius. ${ }^{51}$

In his catalogue of Breslau musical manuscripts, Emil Bohn also included a collection of very interesting sets of part books, which are also of great interest for the history of musical culture in Bohemia. Several of them document the real closeness and connectedness between musical events in Breslau and in Bohemian towns at the end of the sixteenth century. They contain notation of music by composers who were living and working in

47) WALTHER, Johann Gottfried: Cropatius (Georgius) [entry], in: Musicalisches Lexikon oder Musicalische Bibliothec, Wolfgang Deer, Leipzig 1732, p. 193.

48) DLABACZ, Gottfried Johann: Kropácz Georg [entry], in: Allgemeines historisches Künstlerlexikon für Böhmen und zum Theil auch für Mähren und Schlesien, Zweiter Band, J-K, Gottlieb Haase, Praha 1815, cols. 139-140.

49) E.g. GERBER, Ernst Ludwig: Cropatius (Georgius) [entry], in: Neues historisch-biographisches Lexikon der Tonkünstler: welches Nachrichten von dem Leben und den Werken musikalischer Schriftsteller, berühmter Komponisten, Sänger, Meister auf Instrumenten, kunstvoller Dilettanten, Musikverleger, auch Orgel- und Instrumentenmacher, älterer und neuerer Zeit, aus allen Nationen enthält, A. Kühnel, Leipzig 1812, vol. 1, column 822; FÉTIS, François-Joseph: Cropatius (George) [entry], in: Biographie universelle des musiciens et bibliographie générale de la musique, vol. 3, Leroux, Bruxelles 1836, p. 222; BECKER, Carl Ferdinand, in: Die Tonwerke des XVI. und XVII. Jahrhunderts oder systematisch-, chronologische Zusammenstellung der in diesen zwei Jahrhunderten gedruckten Musikalien, Erns Fleischer, Leipzig 1847 even list's Cropatius's print twice, first dated 1548 under the name Cropatius G. (col. 4), then dated 1578 (col. 8) under the name Kropacz G; Cropatius, Georg [entry], in: Musikalisches Conversations-Lexikon. Eine Encyklopädie der gesammten musikalischen Wissenschaften. Für Gebildete aller Stände, eds. Hermann Mendel - August Reissmann, vol. 2, Robert Oppenheim, Berlin 1872, p. 27: it gives both dates: "Venedig 1548 und 1578."

50) EITNER, Robert: Kropácž (Cropatius), Georg [entry], in: Biographisch-Bibliographisches Quellen-Lexikon der Musiker und Musikgelehrten, vol. 5, Breitkopf \& Haertel, Leipzig 1901 (hereinafter EITNER), p. 458.

51) BOHN, Emil: Die Musikalische Handschriften des XVI. und XVII. Jahrhunderts in der Stadtbibliothek zu Breslau, Ein Beitrag zur Geschichte der Musik im XVI. und XVII. Jahrhundert, Hainauer, Breslau 1890 (hereinafter BOHN), pp. 111-112, 236, 334, "Georg. Cropatij. Missa 5v". In the index of compositions on p. 236 Bohn lists Cropatius's Mass in the section "Missa / $5 \mathrm{v}$." with a brief musical incipit of the alto voice notated using letters: "99 B 21. Cropatius (A: -- - a d d h gd d c b a d d ch cis d cis d)". 
Prague, primarily at the emperor's court, and also by a distinct generation of composers from the northern parts of Bohemia, and especially from the German-speaking areas. ${ }^{52}$ One of them is a manuscript that Bohn designates with the numeral $99 .^{53}$ Already by the time the catalogue was made, there were only two preserved part books - Alt and Vagans / Quinta vox - of the original set of probably six volumes. The manuscript, divided into two parts, contains $14+21$ musical settings of the Ordinary or of at least several parts of it. The first part of the manuscript contains mostly six-voice masses, and the second part has Masses for five voices. Composers from the circle of Emperor Rudolf II predominate (Philippe de Monte - 8 Masses, Alexander Utendal - 1 Mass, Jacob Regnart - 2 Masses, Johan de Cleve 1 Mass, Alessandro Orologio - 1 Mass, Tiburzio Massaini - 1 Mass, Georgius Flori - 1 Mass), the most popular central European composer Orlando di Lasso is plentifully represented (8 Masses), and Jacobus Handl Gallus has two compositions in the manuscript; composers are also represented who were professionally engaged in northern Bohemia, Silesia, and Lusatia (Johannes Nucius - 2 Masses, Michael Hess - 2 Masses, Christophorus Köckritz 1 Mass, Gregor Langius - 1 Mass). The manuscript also uniquely preserves compositions by Konrád Leher (Conrad Leherius - 1 Mass), who is basically unknown and is not documented elsewhere. He seems to have come from the Bavarian town Volkach. ${ }^{54}$ Also represented is his best-known compatriot Thomas Elsbeth (Authore Thoma Helsbetho Franco - 1 Mass), who was born in Bavaria in Neustadt near Coburg, but who lived and worked in Frankfurt an der Oder and actually directly in Breslau. ${ }^{55}$

The manuscript was created gradually, as can be seen from inscriptions at the ends of certain Masses of the second part of the manuscript, which contains five-voice Masses. The dates by which the scribes documented the time when the notation was finished range from 10 April 1595 (5 th $^{\text {th }}$ Mass, Orlando di Lasso, Missa s. Credidi) ${ }^{56}$ to 21 or 26 March 1600 (19 $9^{\text {th }}$ Mass, Georgius Florius, Missa s. Come la turturelle). Cropatius's Mass is the last to have been notated, i.e. the $21^{\text {st }}$ in sequence. It appears with only the title Missa without reference to the original, as is the case with most of the other settings of the Ordinary in the manuscript. One may therefore deduce that it is not a parody Mass. In the notation of the vocal part in the volume Quinta vox, the Mass is identified as Missa a 5 Georgio Cropatio Authore,

52) DANĚK, Petr - BAŤA, Jan: Numero Arithmetico notata Series officiorum pro Choro Musico Ustensi (1588) aneb pramen polyfonie plný prekvvapení (Arithmetico notata Series officiorum pro Choro Musico Ustensi [1588] A Source of Polyphony Full of Surprices), Musicologica Istropolitana, vols. X-XI, 2011-2012, pp. 45-67.

53) $\mathrm{BOHN}$, pp. 111-112. A description of the manuscript, which is one of the important sources for the music of composers in the circle of Emperor Rudolf II, is also found in COMBERIATI, Carmelo Peter: Late Renaissance Music at the Habsburg Court. Polyphonic Settings of the Mass Ordinary at the Court of Rudolf II (1576-1612), Gordon and Breach Science Publishers, New York 1987, p. 225.

54) LEHER, Konrad, Volcacensis. Cf. EITNER, op. cit. in footnote no. 50, vol. 6, 1902, p. 117, hereinafter http:// loci.gwi.uni-muenchen.de/Qp/Musikalische_Tätigkeit=Komponist [accessed on 6 April 2020].

55) BIRKENDORF, Rainer: Elsbeth, Thomas [entry], in: Die Musik in Geschichte und Gegenwart, Ludwig Finscher (Hrsg.), Zweite Ausgabe, Personenteil, Band 4, Bärenreiter/Metzler, Kassel u. a. 2000.

56) In our text, the names or designations of Masses contained in the manuscript Bohn 99 are based on the form used in that manuscript. We emphasise this because some better known Masses or ones that were more widespread at the time that were notated in this manuscript are also found in other period sources with variant forms of their titles. 
Cantus Secundus, and in the Altus volume as Missa quinque Vocum Georgii Cropacii. As is apparent from the comments in the course of the Mass, the basic setting is for five voices, the Pleni sunt coeli is for just three voices, and the concluding Agnus Dei (AD), to the contrary, requires six voices. Only two of the five voices have been preserved, so one can hardly judge the compositional quality of the music, but we can determine from the preserved voices that Cropatius's Mass was in the Dorian mode, which was the mode of one of the Masses in the Venice print.

Cropatius's Mass in the Breslau manuscript does not contain a Credo $(\mathrm{Cr})$. The omission of that part of the Ordinary or even of some others is nothing unusual in this source. The scribe or the person who commissioned or was to use this set of polyphonic Ordinary settings had only certain movements copied for some of the Masses, usually the Kyrie (K) and Gloria (Gl), and this is in keeping with the tradition of a particular kind of "Kurzmesse" or Missa brevis, which was employed primarily in the Protestant tradition. ${ }^{57}$ The notation of Cropatius's Mass was not written down until after March 1600, as follows from what is written above. It is thus apparent that at that time the scribe of the Breslau manuscript had the original of the Mass at his disposal. The copy was made carefully, as can also be seen from the fact that in this Mass (and also in others in this manuscript!) there are a number of markings that clearly break down the text placement beneath musical passages. This is not all that usual in the practice of central European manuscripts with notation of polyphonic vocal repertoire. Often, this is an indication that the original may have been a printed specimen. Whatever the scribe of the Breslau manuscript had as an original, it can be documented that Cropatius's Mass was used or at least known in the cultural milieu of Silesia in ca. 1600. The preserved Breslau manuscripts catalogued by Bohn are rare documentation of the breadth of the repertoire that was in current use at the turn of the sixteenth and seventeenth centuries, and Cropatius's Mass fits in interestingly with that peculiar generational, national, and stylistic spectrum.

\section{Contents and structure of the Breslau manuscript Bohn $99^{58}$}

The table below gives a clear summary of important information about the manuscript Bohn 99. The first column gives the number of the composition and the folia on which the manuscript is found. The second column gives the name of the composer of the Mass (or motet) based on inscriptions in the preserved part books. The third column contains the title of the Mass in question again in accordance with the manuscript, and the last column gives a complete listing of the voices employed and all important marginalia written in the manuscript. If abbreviations of movements of the Ordinary are not listed in this column, it means that the complete Ordinary is set to music.

57) KAST, Paul: Die mehrstimmige Messe [entry], in: Musikalische Gattungen in Einzeldarstellungen, Band 2: Die Messe, Deutscher Taschenbuch Verlag und Bärenreiter Verlag, 1985, pp. 50-51 etc.; MORAWSKA, Katerzyna: The History of music in Poland: The Renaissance, Sutkowski Edition Warsaw, Warszawa 2002, p. $148 \mathrm{ff}$.

58) The manuscript Bohn 99, like most of the Breslau musical manuscripts in Bohn's catalogue, is now kept in Berlin: Staatsbibliothek zu Berlin - Preußischer Kulturbesitz, http://www.staatsbibliothek-berlin.de 


\begin{tabular}{|c|c|c|c|}
\hline $\begin{array}{l}\text { Number of the } \\
\text { composition } \\
\text { according to the } \\
\text { manuscript / folia } \\
\text { Altus / Quinta vox }\end{array}$ & Composer & $\begin{array}{l}\text { Title of the } \\
\text { composition } \\
\text { according to the } \\
\text { manuscript }\end{array}$ & $\begin{array}{l}\text { Number of voices / Mass } \\
\text { movements / comments, period } \\
\text { inscriptions Altus / Quinta vox }\end{array}$ \\
\hline $1 / 1^{r}-4^{r} / 1^{r}-3^{r}$ & Philippe de Monte & Missa & 6 \\
\hline $2 / 5^{r}-8^{v} / 4^{r}-7^{r}$ & $\begin{array}{l}\text { Jacobus Handl } \\
\text { Gallus }\end{array}$ & $\begin{array}{l}\text { Missa s. Elisabeth } \\
\text { Zachariae }\end{array}$ & $6 / \mathrm{Ky}-\mathrm{Gl}-\mathrm{Cr}$ \\
\hline $3 / 8^{v}-10^{r} / 7^{r}-8^{v}$ & $\begin{array}{l}\text { Jacobus Handl } \\
\text { Gallus }\end{array}$ & $\begin{array}{l}\text { Missa s. Locutus est } \\
\text { Dominus ad Moysen }\end{array}$ & $\begin{array}{l}\text { 6/Ky }-\mathrm{Gl} \\
\text { Q.v.: Secundus Tenor }\end{array}$ \\
\hline $4 / 10^{v}-12^{r} / 8^{v}-10^{r}$ & \begin{tabular}{|l|} 
Alexander \\
Utendal \\
\end{tabular} & Missa s. Surge propera & $6 / \mathrm{Ky}-\mathrm{Gl}$ \\
\hline $\begin{array}{l}5 / 12 b_{i s}^{r}-15^{v} / \\
11^{r}-15^{r}\end{array}$ & Philippe de Monte & $\begin{array}{l}\text { Officium s. Nasce } \\
\text { la pena mia }\end{array}$ & 6 \\
\hline $6 / 16^{r}-20^{v} / 15^{v}-19^{r}$ & Michael Hess & $\begin{array}{l}\text { Missa s. Usquequo } \\
\text { Domine }\end{array}$ & $\begin{array}{l}6 \\
\text { Q.v.: Secundus Tenor }\end{array}$ \\
\hline $7 / 21^{r}-27^{r} / 19^{v}-24^{v}$ & Orlando di Lasso & Missa s. Si me tenes & 6 \\
\hline $8 / 27^{v}-33^{r} / 25^{r}-29^{v}$ & Orlando di Lasso & Missa s. In principio & 6 \\
\hline $\begin{array}{l}9 / 33^{v}-40^{r} / \\
30^{r}-35^{v}\end{array}$ & Orlando di Lasso & \begin{tabular}{|l} 
Missa s. \\
Congratulamini \\
\end{tabular} & 6 \\
\hline $\begin{array}{l}10 / 41^{r}-45^{v}, \\
45^{v}-46^{v} / 36^{r}-40^{r} \\
40^{v}-41^{v}\end{array}$ & Philippe de Monte & $\begin{array}{l}\text { Missa s. Si ambulavero } \\
\text { / moteto Si } \\
\text { ambulavero, vivificabis } \\
\text { me / 2. pars Illumina } \\
\text { oculos meos }\end{array}$ & $\begin{array}{l}6 \\
\text { Q. v.: Altus } 2\end{array}$ \\
\hline $\begin{array}{l}11 / 47^{r}-52^{v} / \\
42^{r}-47^{v}\end{array}$ & Jacobus Regnart & Missa Quodlibetica & $\begin{array}{l}6 \\
\text { Q.v.: Secundus Altus }\end{array}$ \\
\hline $\begin{array}{l}12 / 53^{v}-59^{r} / \\
48^{v}-53^{r}\end{array}$ & $\begin{array}{l}\text { Johannes } \\
\text { de Cleve }\end{array}$ & $\begin{array}{l}\text { Missa s. Dum transisset } \\
\text { sabbathum }\end{array}$ & 6 \\
\hline $\begin{array}{l}13 / 59^{v}-61^{r} / \\
53^{v}-55^{r}\end{array}$ & $\begin{array}{l}\text { Thomas } \\
\text { Helsbethus }\end{array}$ & $\begin{array}{l}\text { Missa s. Domine quid } \\
\text { multiplicati sunt }\end{array}$ & $\begin{array}{l}\text { 6/K-Gl } \\
\text { A, Q. v.: Authore Thoma } \\
\text { Helsbetho Franco }\end{array}$ \\
\hline $\begin{array}{l}14 / 62^{r} / \\
\text { Not contained in } \\
\text { Q. v. }\end{array}$ & Orlando di Lasso & Missa s. O passi sparsi & $4 / \mathrm{K}-\mathrm{Gl}$ \\
\hline $66^{r} / 56^{r}$ & & & $\begin{array}{l}\text { A., Q. v.: Sequntur Missae } \\
\text { quinq[ue] vocum A }\end{array}$ \\
\hline $1 / 67^{r}-68^{v} / 57^{r}-58^{v}$ & & $\begin{array}{l}\text { Missa s. Transeunte } \\
\text { Domino }\end{array}$ & \begin{tabular}{|l} 
5 / K-Gl \\
Q. v.: Missa ad imitationem \\
Transeunte Domino \\
\end{tabular} \\
\hline $2 / 69^{r}-73^{v} / 59^{r}-63^{r}$ & Johannes Nucius & Missa s. Vestina colli & 5 \\
\hline $3 / 74^{r}-76^{v} / 65^{r}-66^{v}$ & Gregorius Langius & $\begin{array}{l}\text { Missa s. In dieser } \\
\text { weiten Welt }\end{array}$ & $\begin{array}{l}\text { / K - Gl } \\
\text { Q. v.: Sequntur Missa super } \\
\text { suavissimam Cantiunculam In } \\
\text { dieser weiten Welt. Authore } \\
\text { Gregorio Langio à } 5 \\
\end{array}$ \\
\hline
\end{tabular}




\begin{tabular}{|c|c|c|c|}
\hline $\begin{array}{l}\text { Number of the } \\
\text { composition } \\
\text { according to the } \\
\text { manuscript / folia } \\
\text { Altus / Quinta vox }\end{array}$ & Composer & $\begin{array}{l}\text { Title of the } \\
\text { composition } \\
\text { according to the } \\
\text { manuscript }\end{array}$ & $\begin{array}{l}\text { Number of voices / Mass } \\
\text { movements / comments, period } \\
\text { inscriptions Altus / Quinta vox }\end{array}$ \\
\hline $\begin{array}{l}4 / 77^{r}-80^{v} / \\
66^{v}-69^{v}\end{array}$ & $\begin{array}{l}\text { Christophorus } \\
\text { Köckritz }\end{array}$ & $\begin{array}{l}\text { Missa s. Gregorii } \\
\text { Langii motetam: Tota } \\
\text { pulchra es }\end{array}$ & $\begin{array}{l}5 \\
\text { Q. v.: Missa à } 5 \text { super suavissimam } \\
\text { motetam Gregorii Langii Tota } \\
\text { pulchra es, Secundus Tenor }\end{array}$ \\
\hline $5 / 81^{r}-84^{v} / 70^{r}-73^{r}$ & Orlando di Lasso & Missa s. Credidi & $\begin{array}{l}5 \\
1595.10 \text { Aprilis } \\
\text { Q. v.: Finis. Anno 1595. } 10 \text { Aprilis. }\end{array}$ \\
\hline $6 / 84^{v}-90^{r} / 73^{v}-77^{r}$ & Jacobus Regnart & Missa & $5-\mathrm{AD} 6$ \\
\hline $\begin{array}{l}7 / 90^{v}-94^{v} / \\
77^{v}-80^{v}\end{array}$ & Orlando di Lasso & $\begin{array}{l}\text { Missa s. Sydus ex claro } \\
\text { neniens Olympus }\end{array}$ & 5 \\
\hline $8 / 95^{r}-99^{r} / 81^{r}-84^{r}$ & \begin{tabular}{|l|} 
Alexandro \\
Orologio
\end{tabular} & $\begin{array}{l}\text { Missa s. Quando } \\
\text { fra bianche perle }\end{array}$ & $\begin{array}{l}5 \\
\text { Q.v.: } 2 \text { Tenor }\end{array}$ \\
\hline $\begin{array}{l}9 / 99^{r}-103^{v} / \\
84^{v}-89^{r}\end{array}$ & Conrad Leherus & $\begin{array}{l}\text { Missa s. Hispanum } \\
\text { ad coenam }\end{array}$ & $\begin{array}{l}5 \\
\text { A: Authore Conrado Lehero } \\
\text { Volcacensi Franco } \\
\text { Q. v.: 2. Altus } \\
\end{array}$ \\
\hline $\begin{array}{l}10 / 103^{v}-108^{r} / \\
89^{r}-93^{v}\end{array}$ & Tiburtio Massaini & $\begin{array}{l}\text { Missa super } \\
\text { Hypodorium }\end{array}$ & $\begin{array}{l}5 \\
\text { Q. v.: } 2 \text { Tenor } \\
\end{array}$ \\
\hline $\begin{array}{l}11 / 108^{\mathrm{r}}-111^{\mathrm{v}} / \\
93^{\mathrm{v}}-96^{\mathrm{v}}\end{array}$ & Philippe de Monte & Missa & $\begin{array}{l}5 \\
\text { A: Altus } \\
\text { Q. v.: 2dus Tenor } \\
\end{array}$ \\
\hline $\begin{array}{l}12 / 111^{v}-115^{r} / \\
96^{v}-99^{v}\end{array}$ & Philippe de Monte & Missa VII toni & $\begin{array}{l}5 \\
\text { A: Altus } \\
\text { Q. v.: } 2 \text { Tenor } \\
\end{array}$ \\
\hline $\begin{array}{l}13 / 115^{r}-118^{v} / \\
100^{r}-103^{r}\end{array}$ & Philippe de Monte & Missa & $\begin{array}{l}5 \\
\text { A: Altus } \\
\text { Q. v.: } 2 \text { Tenor }\end{array}$ \\
\hline $\begin{array}{l}14 / 118^{v}-122^{r} / \\
103^{r}-105^{\vee}\end{array}$ & Philippe de Monte & Missa & $\begin{array}{l}5 \\
\text { Q. v.: } 2 \text { Tenor }\end{array}$ \\
\hline $\begin{array}{l}15 / 122^{r}-126^{r} / \\
106^{r}-109^{r}\end{array}$ & Orlando di Lasso & $\begin{array}{l}\text { Missa s. Le Berger } \\
\text { et la Bergere }\end{array}$ & $\begin{array}{l}5 \\
\text { Q. v.: } 2 \text { Tenor }\end{array}$ \\
\hline $\begin{array}{l}16 / 126^{v}-130^{v} / \\
109^{v}-113^{r}\end{array}$ & Orlando di Lasso & Missa s. Ite ime dolenti & $\begin{array}{l}5 \\
\text { Q.v.: Tenor } 2 \\
\end{array}$ \\
\hline $\begin{array}{l}17 / 131^{r}-135^{v} / \\
113^{r}-117^{r}\end{array}$ & Horatio Vecchi & $\begin{array}{l}\text { Missa s. Se desio } \\
\text { fuggier }\end{array}$ & \begin{tabular}{|l|} 
Q. v.: 2 Tenor / Finis 13. Maii 99 \\
\end{tabular} \\
\hline $\begin{array}{l}18 / 135^{v}-139^{r} / \\
117^{v}-120^{v}\end{array}$ & Michael Hess & $\begin{array}{l}\text { Missa s. Litaniam } \\
\text { b. M. V. Constantii } \\
\text { Portae }\end{array}$ & $\begin{array}{l}5 \\
\text { A: Finis } 28 \text { Maii Ao. } 99\end{array}$ \\
\hline $\begin{array}{l}19 / 139^{v}-143^{r} / \\
121^{r}-124^{r}\end{array}$ & Georgius Florius & $\begin{array}{l}\text { Missa s. Come } \\
\text { la turturelle }\end{array}$ & $\begin{array}{l}5 \\
\text { A, Q. v.: text not printed } \\
\text { A: Ao. 1600. } 21 . \text { Martii } \\
\text { Q. v.: Missa à } 5 \text { facta ad } \\
\text { imitationem Moduli Gallici Come la } \\
\text { turturelle. Cantus 2. Georgii Florii } \\
\text { Q. v.: Finis. Ao 1600. } 26 \text { Martii }\end{array}$ \\
\hline
\end{tabular}




\begin{tabular}{|l|l|l|l|}
\hline $\begin{array}{l}\text { Number of the } \\
\text { composition } \\
\text { according to the } \\
\text { manuscript / folia } \\
\text { Altus / Quinta vox }\end{array}$ & Composer & $\begin{array}{l}\text { Title of the } \\
\text { composition } \\
\text { according to the } \\
\text { manuscript }\end{array}$ & $\begin{array}{l}\text { Number of voices / Mass } \\
\text { movements / comments, period } \\
\text { inscriptions Altus / Quinta vox }\end{array}$ \\
\hline $\begin{array}{l}20 / 143^{v}-145^{r} / \\
124^{v}-126^{v}\end{array}$ & Johannes Nucius & $\begin{array}{l}\text { Missa s. Chara } \\
\text { Theodoram }\end{array}$ & $5 / \mathrm{Ky}-\mathrm{Gl}$ \\
\hline $\begin{array}{l}21 / 145^{r}-147^{v} / \\
126^{v}-128^{v}\end{array}$ & $\begin{array}{l}\text { Georgius } \\
\text { Cropatius }\end{array}$ & Missa & $\begin{array}{l}5 / \text { without Cr } \\
\text { Q. v.: AD Sex vocum }\end{array}$ \\
\hline
\end{tabular}

\section{The Venetian print of Masses by Jiři Cropatius}

In view of the fact that Cropatius's Venetian print has not been preserved, we can only hypothesise about its origin, form, and content as well as about all of his activity as a composer. The title probably read: Missarum tomus primus quinque vocum iuxta dodecachordi modos, dorii scilicet, hypodorii et lydii accurate compositus, recensque in luce editus (Volume one of Masses for five voices in modes according to the dodecachordon, in Dorian, Hypodorian, and Lydian, carefully composed and recently brought to light). From this, we can deduce that this was the first part of five-voice musical settings of the Ordinary of the Mass according to the "dodecachordon", a classification of twelve modes newly defined by Heinrich Glareanus in the third volume of his treatise Dodecachordon ( $\Delta \Omega \Delta \mathrm{EKAXOP} \Delta \mathrm{ON})$, printed in 1547. Cropatius's print contained Masses in the Dorian, Hypodorian, and Lydian modes. We have no idea whether Cropatius also composed Masses in other modes ${ }^{59}$ or only intended to do so. Nonetheless, even just for the concept behind Cropatius's Venetian print, we have to admire the modernity of his thinking that is indicated. Glareanus's idea of twelve modes had only begun to make headway in Europe in the latter half of the sixteenth century, and from the 1580s we have found no hint that it had found any theoretical acceptance or practical application in the Czech lands. ${ }^{60}$ Cropatius's "new" modal thinking based on a humanistic conception is unique even in comparison with the greatest authorities on composition in the 1580s, i.e. Orlando di Lasso and Palestrina, who were both still using the traditional system of eight modes. In the environment of Italian musical culture, where Glareanus's concept was accepted and developed primarily by Giuseppe Zarlino, ${ }^{61}$ the modal system

59) I.e. Phrygian, Hypophrygian, Hypolydian, Mixolydian, Hypomixolydian, Aeolian, Hypoaeolian, Ionian, and Hypoionian.

60) FULLER, Sarah: Defending the Dodecachordon: Ideological Currents in Glarean's Modal Theory, in: Musical Theory in the Renaissance, ed. Cristle Collins Judd, Routledge, London - New York 2013 (hereinafter COLLINS JUDD), pp. 321-354. Glarean's Dodecachordon does not appear in print in Bohemia until the early $17^{\text {th }}$ century, when Jiř́ Bartholdus Pontanus of Breitenberk had it in his library. The preserved specimen, however, seems not to have been used in practice. It contains no inscriptions and is in an almost exemplary, untouched condition. Cf. Library of the Metropolitan Chapter in Prague, shelf mark Db a 30. Also cf. DANĚK, Petr: Historické tisky vokální polyfonie, rané monodie, hudební teorie a instrumentální hudby v českých zemích do roku 1630 (Historical Prints of Vocal Polyphony, Early Monody, Music Theory, and Instrumental Music in the Czech Lands until 1630), KLP, Praha 2015, pp. 84-85 (hereinafter DANĚK).

61) Le Istitutioni armoniche, 1558/1573 and Dimostrationi armoniche, 1571. Da COL, Paolo: The Tradition and Science: The Institutioni harmoniche of Gioseffo Zarlino. Introduction to the Facsimile Edition, Bibliotheca Musica Bononensis II, in: COLLINS JUDD, op. cit. in footnote no. 60, pp. 373-393. A specimen of the first edition is 
also found acceptance only gradually thanks in part to such composers as Claudio Merulo, Annibale Padovano, and Giovanni and especially Andrea Gabrieli. ${ }^{62}$ There is, of course, another collection worthy of mention by Alexander Utendal, who was working in Bohemia. The title is Septem Psalmi penitentiales, and it dates from back in $1570 ;{ }^{63}$ Cropatius may have been familiar with it. In connection with the Venice edition of Cropatius's Masses, however, one must think quite realistically. Gardano printed Cropatius's Masses not because Cropatius was all that extraordinary a composer, whose "fame" reached as far as Venice, but instead undoubtedly because the composer sought him out and paid for the printing. One may therefore assume that the number of prints was not large, the printing was done frugally, and even after specimens were printed, there was no subsequent concerted effort to distribute them around Italy or Europe. This would also explain why the print is absent today among the preserved European collections of printed music of the sixteenth

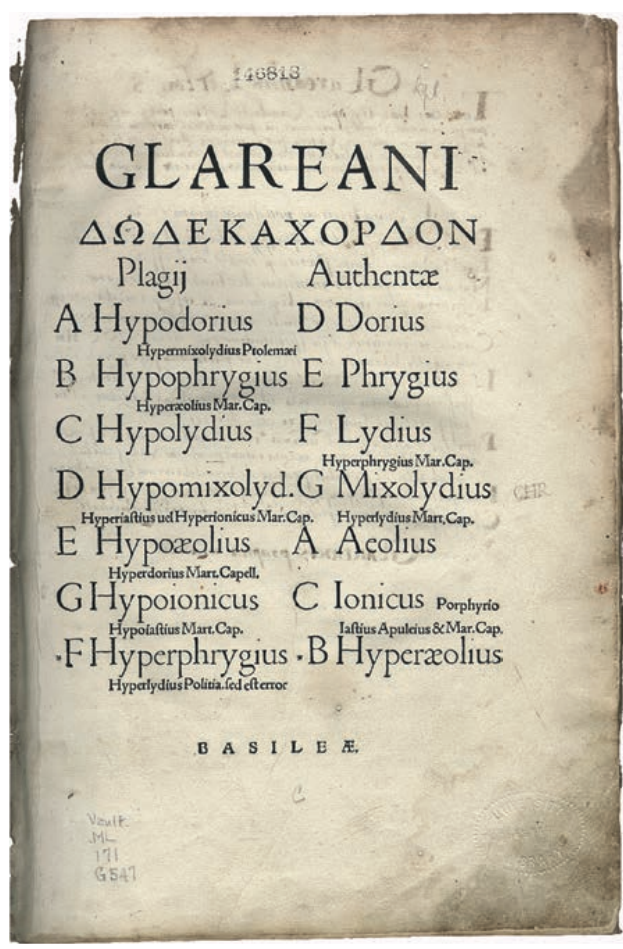

Heinrich Glareanus: Dodecachordon

Print / Tisk, Heinrich Petrus, Basel, 1547

Title page with characteristics of the twelve modes / Titulní strana s charakteristikou dvanácti modů

Private collection / Soukromá sbírka century. The main distributor was probably the composer himself. Nonetheless, there can be no doubt about Cropatius's original

found in Prague at the Capuchin Provincial Library, shelf mark 2 C 31 (1). It is very likely, however, that it did not arrive in Bohemia until after 1600. The original owner was the Italian composer and poet Giovanni Battista Massarengo, who was working in Prague from the beginning of the seventeenth century until his dramatic death; for more information, see HRADILOVÁ, Marta: Italština v knihovně kapucínského konventu na Hradčanech (Italian in the Library of the Capuchin Convent at Hradčany), in: Libri magistri muti sunt. Pocta Jaroslavě Kašparové, eds. Alena Císařová Smítková - Andrea Jelínková - Milada Svobodová, Knihovna Akademie věd ČR, Praha 2013, pp. 335-346; more recently HRADILOVÁ, Marta: Giovanni Battista Massarengo and his Prague Library, La Bibliofilía. Rivista di Storia del Libro e di Bibliografia, vol. 120, no. 2, 2018, pp. 201-208; DANĚK, op. cit. in footnote no. 60, p. 91 .

62) Cf. e.g. the print Madrigali et Ricercari di Andrea Gabrieli a quattro voci, Venezia: Angelo Gardano 1589. RISM A/I G 77.

63) UTENDAL, Alexander: Septem Psalmi penitentiales, adiunctis ex prophetarum scriptis orationibus eiusdem argumenti quinqué, ad Dodecachordi modos duodecim, Noribergae: Theodor Gerlach 1570. RISM U 119; BOSSUYT, Ignace: Die „Psalmi Poenitentiales" (1570) des Alexander Utendal. Ein künstlerisches Gegenstück der Bußpsalmen von O. Lassus und eine praktische Anwendung von Glareans Theorie der zwölf Modi, Archiv für Musikwissenschaft, vol. 38, 1981, no. 4, pp. 279-295; POWERS, Harold: Is mode real? Pietro Aron, the octenary system, and polyphony, in: COLLINS JUDD, op. cit. in footnote no. 60, pp. 169-212, especially p. 171. 
activities as a composer. The evidence consists of not just the mentions of Gardano's print and the copy of the Mass in the Breslau manuscript, but also the testimony of his fellow travellers to the Holy Land, his decision to stay behind and compose at the St. Saviour's Monastery in Jerusalem, and the gift to Jiři Mehl in the form of a five-voice Officium Missae. Where he learned the art of composition is also unclear, of course. It was probably during his studies abroad, because if he had followed the path of domestic Bohemian composers from the milieu of the literary confraternities and Latin schools, we would surely have found his compositions preserved in the repertoire owned by Bohemian literati. As a composer, however, Cropatius stood apart from the milieu of the Bohemian townsmen in several ways, as we have already shown in previous parts of this text.

\section{Cropatius's print in the production of Gardano's press in $1578^{64}$}

If we consider the production of Gardano's printing press in the year when Cropatius's print was issued, and if we attempt to make certain generalisations and comparisons, we find that in that year Angelo Gardano published 23 editions of printed music. Most of them were in quarto format and therefore were part books. Only the title Missarum liber primus by Constanzo Porta (1529-1601) ${ }^{65}$ was printed in folio format in a costly manner, and it contained seven Masses for four voices (Missa primi toni, Missa secundi toni, Missa tertii toni, Missa quarti toni, Missa quinti toni, Missa sexti toni, Missa de beata virgine), two for five voices (Missa Descendit angelus, Missa Mortuorum), and three for six voices (Missa Quemadmodum, Missa Audi filia, Missa La, sol, fa, re, mi), all printed on 130 pages in the style known as "Chorbuch".

Cropatius's print was more modest in every respect. It contained only three Masses, making it comparable, for example, to another collection of Masses that Gardano printed that same year, the Liber primum missarum by Constanzo Antegnati (1549-1624) for six and eight voices. ${ }^{66}$ This print, like Cropatius's, contained only three musical settings of the Ordinary of the Mass (Missa A l'aqua sagra, Anchor ch'io possa dire, Nasce la pena mia), so volumes for individual voices were just 17 pages long in quarto format, while a volume that contained two voices (e.g. secundus chorus altus, secundus chorus tenor) was 22 pages long.

The production of Gardano's printing press from 1578 offered nearly all of the period's types and genres: motets are the most numerous (7), followed by madrigals (6), Masses (4), psalms for Vespers (3), ricercari (1), canzoni spirituali (1), and a collection of unique dance compositions for voices and instruments by Giorgio Mainerio (ca. 1530/1540-1582) titled Il primo libro de balli a quattro voci.$^{67}$ It is noteworthy that with just a single exception, the anthology Madrigali ariosi a quatro voci, composti da diversi eccellentissimi autori. Libro

64) Processed in accordance with AGEE, op. cit. in footnote no. 40, especially pp. 219-223 and RISM Online.

65) RISM A/I P 5180.

66) RISM A/I A 1260.

67) RISM A/I M 187. 
primo ${ }^{68}$ Gardano published only collections of music by single composers that year. ${ }^{69}$ Italians are predominant among them, of course. Besides Jiří Cropatius, the exceptions are the composers of Spanish origin Don Ferdinando de las Infantas and Pietro/Pedro Valenzola. ${ }^{70}$ The printed edition of madrigals by Philippe de Monte titled Il settimo libro delli madrigali a cinque voci ${ }^{71}$ has connections of a kind to Bohemia and central Europe because it is dedicated to Emperor Rudolf II, and the foreword is dated February 1578 in Vienna. ${ }^{72}$ Gardano, however, printed Monte regularly, and he issued most of his prints repeatedly. ${ }^{73}$

\begin{tabular}{|l|l|l|l|}
\hline $\begin{array}{l}\text { Author's name (listed } \\
\text { alphabetically) }\end{array}$ & $\begin{array}{l}\text { Abbreviated title / contents of the printing } \\
\text { RISM }\end{array}$ & $\begin{array}{l}\text { No. of } \\
\text { voices }\end{array}$ & Format \\
\hline multiple authors & $\begin{array}{l}\text { Madrigali ariosi a quatro voci, composti da diversi } \\
\text { eccellentissimi authori, novamente con somma diligentia } \\
\text { ristampati } \\
\text { RISM 157820 }\end{array}$ & 4 & $4^{\circ}$ \\
\hline $\begin{array}{l}\text { Antegnati, Constanzo } \\
\text { (1549-1624) }\end{array}$ & $\begin{array}{l}\text { Liber primus missarum sex et octo vocum } \\
\text { RISM A/I A 1260 }\end{array}$ & 6,8 & $4^{\circ}$ \\
\hline $\begin{array}{l}\text { Asola, } \\
\text { Giovanni Matteo } \\
\text { (ca.1532-1609) }\end{array}$ & $\begin{array}{l}\text { Vespertina omnium solemnitatum psalmodia, iuxta } \\
\text { decretum sacrosancti Tridentini concilii, duoque; B. Virginis } \\
\text { cantica primi toni, cum quatuor vocibus ... primus chorus } \\
\text { extat etiam secundus chorus, ad pares voces concinendus } \\
\text { RISM A/I A 2532 }\end{array}$ & 4 & $4^{\circ}$ \\
\hline $\begin{array}{l}\text { Asola, } \\
\text { Giovanni Matteo }\end{array}$ & $\begin{array}{l}\text { Secundus chorus vespertinae omnium solemnitatum } \\
\text { psalmodiae, iuxta sacrosancti Tridentini concilii decretum, } \\
\text { duoque B. Virginis cantica, primi toni, vocibus quatuor } \\
\text { paribus concinendus } \\
\text { RISM A/I A 2538 }\end{array}$ & 4 & $4^{\circ}$ \\
\hline $\begin{array}{l}\text { Balbi, Lodovico } \\
\text { (1545-1604) }\end{array}$ & $\begin{array}{l}\text { Ecclesiasticarum cantionum quatuor vocum omnibus } \\
\text { Adventus dominicis, nec non Septuagesimae, Sexagesimae, } \\
\text { luinquagesimae, simul atque quibuscunque totius anni } \\
\text { opportunitatibus deservientium } \\
\text { RISM A/I B 737 }\end{array}$ & 4 & $4^{\circ}$ \\
\hline
\end{tabular}

68) RISM 157820; it is noteworthy that this print has been preserved only at the Biblioteka Cyfrowa Uniwersytetu Wroctawskiego in Wroclaw, Poland, RISM Recueils Imprimés XVIe - XVIIe siècles, p. 306. However, the specimen comes from Legnica, from the library of Prince George Rudolf of Liegnitz; cf. KOLBUSZEWSKA, Aniela: Katalog zbiorów muzycznych legnickiej biblioteki księcia Jerzego Rudolfa „BIBLIOTHECA RUDOLPHINA“, Legnickie Towarzystwo Muzyczne, Legnica 1992, p. 24. The print is part of a noteworthy composite volume, where we also find several more Italian prints, including three of Gardano's from 1578 (Filippo Nicoletti, Pietro Valenzola, Madrigali ariosi). Accessed from: https://bibliotekacyfrowa.pl/ dlibra/publication/63908/edition/63824?language=en [accessed on 6 April 2020].

69) Another collective print of a certain kind is the uniquely preserved Motectorum liber secundus, RISM 1578², RISM A/I L 2806, because it contains music by two composers.

70) RISM A/I V 144; there are also three specimens of this relatively plentifully preserved print in Poland. http://www.rism.info/index.php?id=31\&L=0

71) RISM A/I M 3366.

72) Van DOORSLAER, Georg: La vie et les oevres de Philippe de Monte 1521-1603, Georg Olms Verlag, Bruxelles 1921, pp. 115-116.

73) Ibid, e.g. p. 116. 


\begin{tabular}{|c|c|c|c|}
\hline $\begin{array}{l}\text { Author's name (listed } \\
\text { alphabetically) }\end{array}$ & $\begin{array}{l}\text { Abbreviated title / contents of the printing } \\
\text { RISM }\end{array}$ & $\begin{array}{l}\text { No. of } \\
\text { voices }\end{array}$ & Format \\
\hline $\begin{array}{l}\text { Infantas, Don } \\
\text { Ferdinando de las } \\
(1534-\text { ca. 1610) }\end{array}$ & $\begin{array}{l}\text { Sacrarum varii styli cantionum tituli Spiritus sancti, liber } \\
\text { primus cum quatuor vocibus } \\
\text { RISM A/I I } 37\end{array}$ & 4 & $4^{\circ}$ \\
\hline $\begin{array}{l}\text { Ingegnieri, } \\
\text { Marc'Antonio } \\
\text { (ca. 1535-1592) }\end{array}$ & $\begin{array}{l}\text { Il primo libro de madrigali a quatro voci, novamente con ogni } \\
\text { dilligentia ristampati } \\
\text { RISM A/I I } 51\end{array}$ & 4 & $4^{\circ}$ \\
\hline $\begin{array}{l}\text { Cropatius, Georgius } \\
\text { (ca. 1550-?) }\end{array}$ & Georg Cropatii missarum tomus primus & 5 & $4^{\circ}$ \\
\hline $\begin{array}{l}\text { Lasso, Orlando di } \\
(1532-1594)\end{array}$ & $\begin{array}{l}\text { Sacrae cantiones (vulgo motecta appellatae) quinque, et } \\
\text { sex vocum, tum viva voce tum omnis generis instrumentis } \\
\text { cantatu commodissimae, liber tertius } \\
\text { RISM A/I L 910 }\end{array}$ & $\begin{array}{l}5,6 \text { or } \\
\text { more }\end{array}$ & $4^{\circ}$ \\
\hline Lasso, Orlando di & $\begin{array}{l}\text { Liber septimus ... sacrorum cantuum quinis vocibus } \\
\text { concinendorum, quinq: instrumentorum sonis, et vocum } \\
\text { concentibus adaptari possunt } \\
\text { RISM A/I L 911 }\end{array}$ & 5 & $4^{\circ}$ \\
\hline $\begin{array}{l}\text { Lombardi, Bartolomeo } \\
\text { (?-?) }\end{array}$ & $\begin{array}{l}\text { Mottectorum liber secundus cum quinque vocibus } \\
\text { RISM A/I L } 2806\end{array}$ & 5 & $4^{\circ}$ \\
\hline $\begin{array}{l}\text { Luzzaschi, Luzzasco } \\
\text { (ca. 1545-1607) }\end{array}$ & $\begin{array}{l}\text { Il Secondo. Libro. De. Ricercari. | a Quattro voci, DI Luzzasco } \\
\text { Luzzaschi | Ferrarese partit. | } 1578 \\
\text { Preserved only in manuscript }\end{array}$ & 4 & $4^{\circ}$ \\
\hline $\begin{array}{l}\text { Mainerio, Giorgio } \\
\text { (ca. 1535-1582) }\end{array}$ & $\begin{array}{l}\text { Il primo libro de balli a quattro voci accommodati per cantar } \\
\text { et sonar d'ogni sorte de istromenti } \\
\text { RISM A/I M } 187\end{array}$ & 4 & $4^{\circ}$ \\
\hline $\begin{array}{l}\text { Massaini, Tiburtio } \\
\text { (ca. 1550-ca. 1609) }\end{array}$ & $\begin{array}{l}\text { Missae quinque et sex vocum ... Missa Rorate coeli, quinque } \\
\text { voc.; Missa Nuncium vobis, quinque voc.; Missa Omnes } \\
\text { gentes, sex voc.; liber primus } \\
\text { RISM A/I M } 1269\end{array}$ & 5,6 & $4^{\circ}$ \\
\hline $\begin{array}{l}\text { Merulo, Claudio } \\
(1533-1604)\end{array}$ & $\begin{array}{l}\text { Liber primus sacrarum cantionum quinque vocibus } \\
\text { RISM A/I M } 2358\end{array}$ & 5 & $4^{\circ}$ \\
\hline Merulo, Claudio & $\begin{array}{l}\text { Liber secundus sacrarum cantionum, quinque vocibus } \\
\text { RISM A/I M } 2359\end{array}$ & 5 & $4^{\circ}$ \\
\hline $\begin{array}{l}\text { Monte, Philippe de } \\
\text { (1521-1603) }\end{array}$ & $\begin{array}{l}\text { Il settimo libro delli madrigali a cinque voci } \\
\text { RISM A/I M } 3366\end{array}$ & 5 & $4^{\circ}$ \\
\hline $\begin{array}{l}\text { Nicoletti, Filippo } \\
\text { (ca.1555-ca.1620) }\end{array}$ & $\begin{array}{l}\text { Il primo libro de madrigali ... a cinque voci } \\
\text { RISM A/I N } 676\end{array}$ & 5 & $4^{\circ}$ \\
\hline $\begin{array}{l}\text { Pelio, Giovanni } \\
\text { (?-?) }\end{array}$ & $\begin{array}{l}\text { Il primo libro delle canzoni spirituali a cinque voci } \\
\text { RISM A/I P } 1147\end{array}$ & 5 & $4^{\circ}$ \\
\hline
\end{tabular}

74) Preserved in a period copy, Bologna, Convento di S. Francesco, Biblioteca Martini; LADEWIG, James: The Use of Opens Score as a Solo Keyboard Notation in Italy ca. 1530-1740, in: Essays in Honor of John F. Ohl: A Compendium of American Musicology, Northwestern University Press, Evaston, Illinois 2001, p. 78, 84. RISM ID no.: 859000063. 


\begin{tabular}{|l|l|l|l|}
\hline $\begin{array}{l}\text { Author's name (listed } \\
\text { alphabetically) }\end{array}$ & $\begin{array}{l}\text { Abbreviated title / contents of the printing } \\
\text { RISM }\end{array}$ & $\begin{array}{l}\text { No. of } \\
\text { voices }\end{array}$ & Format \\
\hline $\begin{array}{l}\text { Pordenone, } \\
\text { Marc'Antonio } \\
\text { (ca. 1535-ca. 1590) }\end{array}$ & $\begin{array}{l}\text { Il quinto libro de madrigali a cinque voci } \\
\text { RISM A/I P 5105 }\end{array}$ & 5 & $4^{\circ}$ \\
\hline $\begin{array}{l}\text { Porta, Constanzo } \\
\text { (ca.1528-1601) }\end{array}$ & $\begin{array}{l}\text { Missarum liber primus } \\
\text { RISM A/I P 5180 }\end{array}$ & $4,5,6$ & Folio \\
\hline $\begin{array}{l}\text { Rossi, Flaviano } \\
\text { (?-?) }\end{array}$ & $\begin{array}{l}\text { Psalmorum vesperarum omnium totius anni dierum festorum } \\
\text {.. lib. primus ... quatuor vocum } \\
\text { RISM A/I R 2737 }\end{array}$ & 4 & $4^{\circ}$ \\
\hline $\begin{array}{l}\text { Valenzola, Pietro/ } \\
\text { Pedro } \\
\text { (?-?) }\end{array}$ & $\begin{array}{l}\text { Madrigali ... a cinque voci, con uno a sei, et uno dialogo } \\
\text { a otto ... libro primo } \\
\text { RISM A/I V 144 }\end{array}$ & $5,7,8$ & $4^{\circ}$ \\
\hline
\end{tabular}

With respect to quantity, the number and reputations of the composers, and content, the production of the printer Angelo Gardano in 1578 is comparable to the production of another important Venetian family of printers, Scotto, but the latter printed not only music, but also books in the fields of medicine, philosophy, and theology. ${ }^{75}$ After the death of the prominent printer Girolamo Scotto in 1572, his printing press was run by his nephew Melchiorre Scotto, but the title pages continued to bear the name of his more famous uncle (herede di G. Scotto). In 1578 that printing press issued two dozen prints of vocal polyphony, while in terms of genre, the published works are similar to those published by Angelo Gardano. The printers differ in their choices of composers, of course, but the profiles are similar. There are some composers whose music was published by both printers (Philippe de Monte, Infantas, Massaini). That year, however, Scotto gave preference to printing collections of music by multiple composers, and unlike Gardano, he did not publish Masses at all. ${ }^{76}$ It is therefore understandable that Jiří Cropatius chose Angelo Gardano to print his Masses.

\section{Conclusion}

Although until now Jiři Cropatius has tended to be seen as just a name in encyclopaedias and musical dictionaries, today the better availability of old literature and sources and also their modern processing have allowed us to add new and interesting facts to the mosaic of his life. From an unknown Protestant from Teplice, the addition of new findings has shown him to be a traveller and a convert, and from a poet with Wittenberg training, he has become an acknowledged musician and an expert on languages who befriended the Patriarch of Alexandria and who wrote texts in praise of Giuseppe Zarlino. We can still view Jiří Cropatius as a composer of Masses, one of which has been partially preserved in Berlin, and in this article it is presented in broader contexts for the first time. For the future, one can only hope that over time we will learn even more details about his life and that, above all, Cropatius's Venetian print will perhaps be found. Although the music of

75) BERNSTEIN, Jane A.: Music Printing in Renaissance Venice: the Scotto Press, 1539-1572, Oxford University Press, 1998.

76) Cf. RISM Online, Scotto 1578. 
Jiří Cropatius is documented only by an illustrative fragment about which we cannot now make any reasonable judgement, it is clear that, like its composer, it belonged to the musical culture of its day. From the existing musicology literature, we have become accustomed to think basically in terms of two types of composers of vocal polyphony who took part in the shaping of the era before the Battle of White Mountain or the Rudolphine stage of musical culture in Bohemia: composers from the milieu of the literary confraternities, and composers of foreign origin, the vast majority of whom came to Bohemia in connection with the Habsburg court, whether during the governorship of Ferdinand of Tyrol or during the period when Emperor Rudolf II had his residence in Prague. The former type of composer learned music primarily through practice during studies at school, and that practice then continued for a lifetime through singing at church. These composers arrived at their style mainly by learning the works of respected composers from imported printed music (Jacobus Clemens non Papa, Nicolas Gombert) and by the imitation of distinguished domestic composers. The court composers and other musicians who wrote music had a higher level of skill, because they usually spent their years of study and of learning music in direct contact with the exceptional composers of their day (Orlando di Lasso, Philippe de Monte), who trained them systematically. These court musicians also drew inspiration from their travels around Europe, and as the sixteenth century progressed, Italian musical culture played an increasingly important role in this. Heretofore, it has been difficult for us to assign the two composers who were working in Bohemia, Jacobus Handl Gallus and Kryštof Harant, to one of these two categories. Jiř́ Cropatius now joins them. One of the conclusions of our text may therefore be that there are probably more of these isolated figures who did not belong to either of the two large groups mentioned above. According to our findings, one must search primarily in the milieu of the aristocratic courts and residences and in connection with the activities of the monasteries and ecclesiastical orders.

Address: Marta Vaculínová, Centre for Classical Studies at the Institute of Philosophy, Czech Academy of Sciences, Na Florenci 1420/3, 11000 Praha 1, Czech Republic

E-mail:vaculinova@ics.cas.cz

Address: Petr Daněk, Institute of Art History, Czech Academy of Sciences, Husova 4, 11000 Praha 1, Czech Republic

E-mail:danek@udu.cas.cz 
Incipits of preserved movements of the Mass by Jiří Cropatius / Incipity dochovaných částí mše Jiř́ho Cropatia

Altus

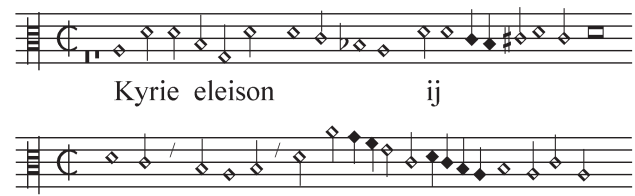

Christe eleison ij
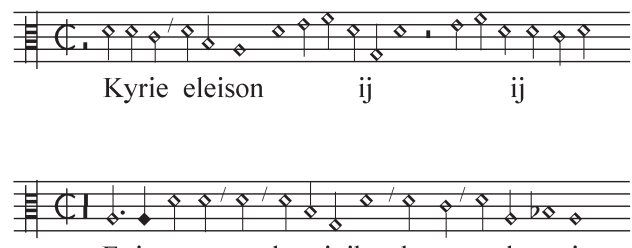

Et in terra pax hominibus bonae voluntatis

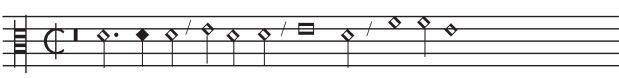

Qui tollis peccata mundi suscipe
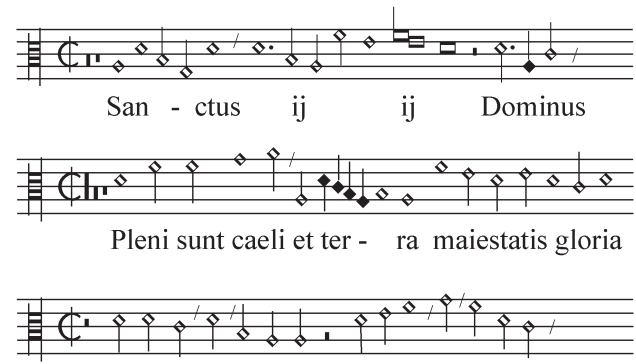

Osanna in excelsis

ij
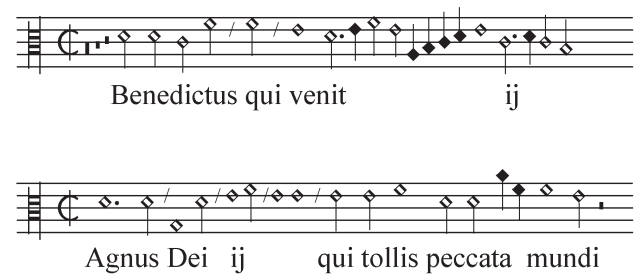

Missa a 5 Georgio Cropatio Authore

Bohn Ms. mus 99 (Altus, Quinta vox)

Staatsbibliothek zu Berlin - Preußischer Kulturbesitz

\section{Quinta vox}
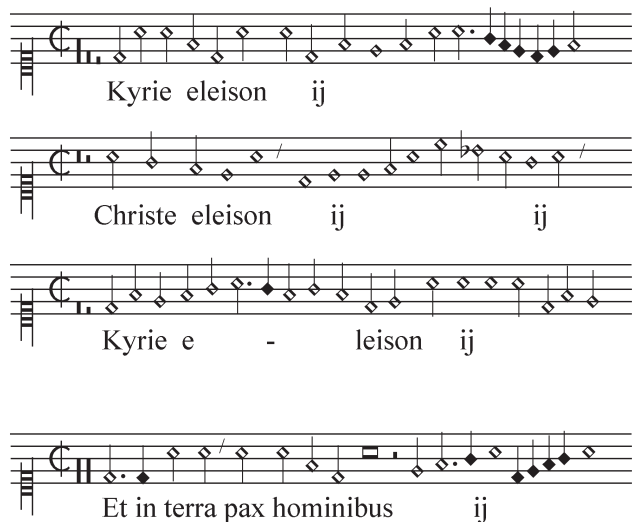

Et in terra pax hominibus ij
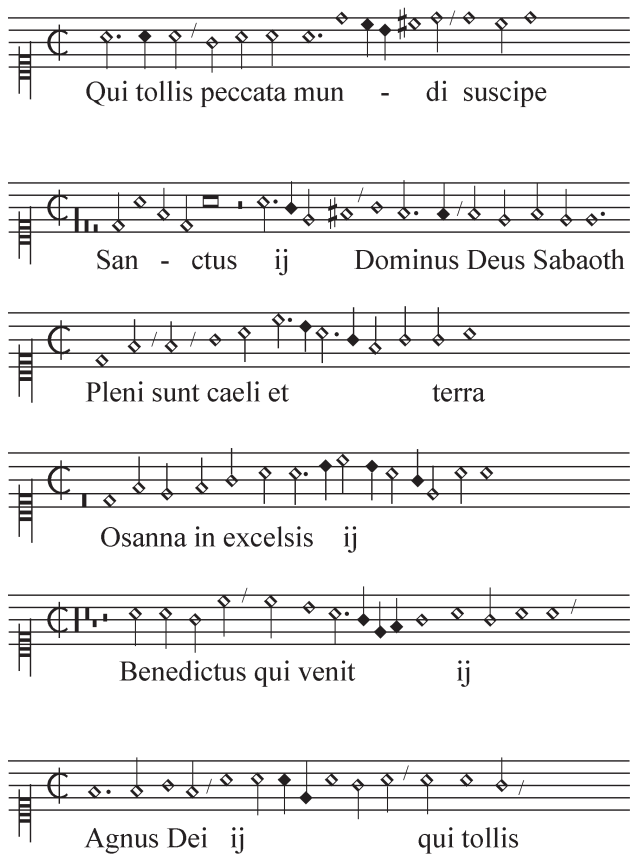


\section{Musicus et poeta trilinguis. Nové poznatky o životě a díle Jiřho Cropatia Teplického}

\section{Marta Vaculínová - Petr Daněk}

Je pozoruhodné, jak často je v literatuře, která se zabývá hudební kulturou v Čechách či dějinami evropského nototisku, zmiňován Jiří Cropatius (sám se podepisoval Georgius Cropatius nebo Cropacius, z pramenů a literatury je známý i jako Georg Kropácz, Kropácž, Jorgius Cropatius, Jurge, jeho jméno však bývalo komoleno i na Coppacius či Cropalius neboli Giorgio Cropalioํ). Četnost citací tohoto jména je zvláštní vzhledem k tomu, že o životě či díle jeho nositele je toho doposud známo opravdu velice málo. Jiří Cropatius je připomínán především proto, že v roce 1578 vydal v Benátkách v přední evropské oficíně Angela Gardana, specializované na tisk not, titul Missarum tomus primus quinque vocum iuxta dodecachordi modos, dorii scilicet, hypodorii et lydii accurate compositus, recensque in luce editus. Do dnešní doby se exemplář tohoto tisku nedochoval či dosud nebyl nalezen. Nicméně již jen ten fakt, že autor, který pocházel z měštanské rodiny protestantského vyznání a snažil se uchytit v prostředí českých měst (Teplice, Louny, Rokycany, Praha), vydal koncem sedmdesátých let 16. století sborník vícehlasých zhudebnění mší v benátské tiskárně, je natolik historicky výjimečný a ojedinělý, že již řadu let vybízí k hlubší úvaze a studiu.

\section{Původ Jiř́ho Cropatia, jeho studia a působení v Čechách}

Informace o původu, životě a působení Jiř́ho Cropatia ${ }^{2}$ byly dosud vyvozovány především z jeho nečetných tisků př́ležitostné poezie, vydaných mezi lety 1574-1575 v tiskárnách Jiř́iho Nigrina a Jiř́ho Jakubův Dačického v Praze. Podařilo se nám však zjistit další podrobnosti, které jeho zatím stručný životopis pozoruhodně rozšírilly.

Cropatius se narodil kolem roku 1550 v Teplicích (Teplicenus, Teplicensis) v nekatolické rodině. O počátcích jeho studií nevíme nic konkrétního, sám píše, že odmala jej zajímaly

1) Jako Georgius Cropalius, autor pětihlasé mše vydané v Benátkách 1578, například figuruje v přepracované Gessnerově univerzální bibliografii: Bibliotheca instituta et collecta primum per Conradum Gessnerum ... deinde locupletata ... cum priorum tum novorum authorum opusculis, ex instructissima Vienensi Austriae Imperatoria Bibliotheca amplificata, per Iohannem Iacobum Frisium Tigurinum, Tiguri: Christophorus Froschauer 1583, s. 267. Jakob Frisius doplnil bibliografii, přepracovanou již v roce 1574 Iosiasem Simlerem, o starší i nové tituly z císařské dvorské knihovny ve Vídni. Dalo by se tedy předpokládat, že tam Cropatiưv tisk tehdy byl.

2) Stručně o jeho životě a díle TRUHLÁŘ, Josef - HRDINA, Karel - HEJNIC, Josef - MARTÍNEK, Jan: Rukovět' humanistického básnictví v Čechách a na Moravě 1 (dále jen Rukovět), Academia, Praha 1966, s. 496-497. 
jazyky, kromě latiny a řečtiny projevoval zejména afinitu $\mathrm{k}$ hebrejštině, s níž se mohl snad seznámit v početné teplické židovské komunitě3 nebo spíše později za vitenberských studií. Užíval ve svých tiscích variantně také češtinu a později se dá předpokládat i znalost němčiny a italštiny. O znalosti jazyků píše Cropatius v předmluvě k jednomu ze svých tisků:

„Studium jazyků není jen užitečné, ale přináší také ušlechtilé potěšení ducha, když mohou přmo z pramene čerpat živý hlas Boži ti, kteř́ čtou hebrejsky, a poznaji dobré autory řecké a latinské v jazycích, kterými oni sami za svého života hovorili. Kdyžjsem sám začal chápat tuto užitečnou a př́jemnou stránku znalosti jazyků, hned v chlapeckém věku jsem si dal práci, abych si osvojil alespoň maličkou část této velké a vznešené látky a aby mi jakoby po právu patrila.“4

Znalost tří svatých jazyků si Cropatius nepochybně prohloubil při studiích na univerzitě ve Vitenberku, kam se zapsal 4. prosince 1569 jako Georgius Cropacius Vandalus. ${ }^{5}$ Setrval zde pravděpodobně do začátku roku 1574, kdy ještě autorsky participuje na tiscích s vitenberským impressem. ${ }^{6}$ Pak odchází do Prahy, kde je autorsky činný v letech 1574-1575. Z tamních intelektuálů mu nejblíže stojí tehdy již uznávaný editor a básník Tomáš Mitis. Mitis navštěvoval teplické lázně, ${ }^{7}$ mohl se tedy s Cropatiem znát už z jeho rodiště.

Zpočátku zastává Cropatius funkci preceptora Balthasara, syna místokancléře Království českého Jiřího Mehla ze Střelic. Jiří Mehl, protestant z Vratislavi a šlechtic, jenž vynakládal nemalé částky na svou osobní reprezentaci, byl známý jako mecenáš umění, bibliofil a pozoruhodná je také jeho renesanční rekonstrukce hradu Grabštejna. ${ }^{8} \mathrm{O}$ jeho zájmu o hudbu však není nic známo kromě zmínky v předmluvě, kterou mu věnoval právě Jiří Cropatius. Z ní se také poprvé dovídáme o Cropatiově aktivní skladatelské činnosti. Zároveň s básní

3) V Teplicích je k roku 1554 doložena židovská škola a počet obyvatel židovské komunity postupně narůstá, viz BURGEROVÁ, Lenka - SPÁLA, Radek: Židé v Teplicích - 600 let historie, Jan Zykmund, Teplice 2014, s. 8.

4) V předmluvě ke Carmen ad filium Dei, Pragae: Georgius Nigrinus 1575, Alb: „Neque vero utile tantum est hoc linguarum studium: sed etiam liberalem animis voluptatem affert: dum vivam DEI vocem in sanctis scripturis haurire videntur ii, qui hebraea legunt: et bonos autores, Graecos et Latinos cognoscunt in ea lingua, qua ipsi, cum viverent, sunt locuti. Hanc ergo cognitionis linguarum utilitatem et suavitatem, cum ego quoque intelligere caepissem: statim a pueritia in hanc curam studiose incubui, ut magnae et honestae rei quantulamcunque partem propriam mihi facerem, et meo quasi iure possiderem."

5) Album academiae Vitebergensis, Vol. 2: Ab a. ch. MDII usque ad a. MDCII, Niemeyer, Halle 1894, s. 172. Byl zapsán bez poplatku mezi těmi, kdo byli „gratis inscripti“. Označení „Vandalus“ mělo v té době široký význam, mohlo se vztahovat na obyvatele Pobaltí, Pomořan, Ruska, Pruska, Polska i sousedních států, zde je však užito pravděpodobně ve významu „Slovan".

6) Konkrétně prispěl do tisku Felixe Chrudimského Historia passionis (Rukovět' 2, 135-136; Verzeichnis der im deutschen Sprachbereich erschienenen Drucke des 16. Jahrhunderts [dále VD16] ZV 18634) a též do tři dalších príležitostných tisků českých studentů ve Vitenberku, výčet Rukovět' 1 , s. 497.

7) Jeho Ode de thermis Teplicensibus však vznikla již před rokem 1561, viz Rukovět' 3, s. 359.

8) Viz ŠŤOVÍČEK, Jan: Renesanční bibliofil Jiří Mehl ze Střelic, Fontes Nissae, č. VI, 2005, s. 6-23. O Mehlovi jako adresátovi dedikací viz STEINMANN, Marc: Der Libellus gnomologicus des Joachim Camerarius (1569): Bemerkungen zur Entstehungs- und Textgeschichte sowie zur pädagogischen Intention, in: Camerarius Polyhistor: Wissensvermittlung im deutschen Humanismus, ed. Thomas Baier, Narr Francke Attempto, Tübingen 2017, s. 95-97. O rekonstrukci Grabštejna WINZELER, Marius: Kaple sv. Barbory na hradě a zámku Grabštejn, online: http://www.mikroreg.info/index.aspx?rub=112 (zde i starš́ literatura). 
De adventu Iesu Christi daroval totiž Mehlovi také mešní officium pro pět hlasů složené podle nějakého moteta:

„K tomuto nepatrnému dárečku jsem připojil také mešni oficium, které jsem nedávno složil pro pět hlasů na motiv jednoho moteta, protože zájem o poezii se dá výborně spojit se zájmem o hudbu a ty máš rád neménè jedno než druhé. Proto tě snažně znovu a znovu prosím, abys oba dárečky, byt nepatrné a bezvýznamné, prijal mile a laskavě a nepřestal mi pomáhat a podporovat mne. Jindy, až přijde vhodný čas a Múzy mi budou více přát, pokusím se ti predložit něco závažnějšího a většího. A bude pro mne největší výzvou, když pocítim, že jsi toto neumèlé dílo prijial s př́znivě nakloněnou mysli.".9

Nevíme, jak dlouho byl Cropacius v Mehlových službách. Podle dedikací tisků se zdá, že se již nedlouho po napsání oné předmluvy ohlíží po jiném místě - postupně v příležitostných tiscích oslovuje městské rady Rokycan, Loun, Starého a Nového Města pražského. ${ }^{10}$ Zřejmě se však v Čechách neuchytil, jeho stopa mizí, dokud jej roku 1578 neobjevujeme na cestě do Svaté země.

\section{Cropatius v Itálii a na cestě do Svaté země}

Cropatius cestoval do Jeruzaléma z Padovy, kde snad studoval s Hansem von Arnim, jenž byl také účastníkem výpravy. ${ }^{11} \mathrm{Z}$ jeho podrobných cestovních deníků čerpal Philipp Han pro Arnimovo pohřební kázání. ${ }^{12}$ Cestou v Benátkách vydal Cropacius u Antonia Gardana soubor pětihlasých zhudebnění mešního ordinaria, jehož plný titul je znám, ale neví se o žádném dochovaném exempláři. Tvrzení o Cropatiově pobytu v Padově může snad podpořit jedno literární svědectví. V rukopise významného italského humanisty Bernardina Baldiho

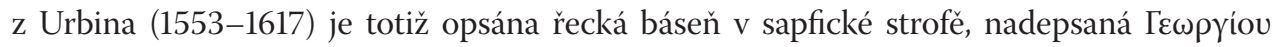

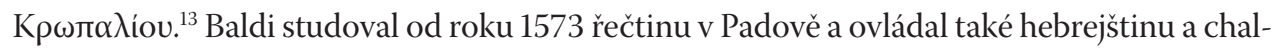
dejštinu. Je možné (i když se to nedá s jistotou tvrdit), že právě v době padovských studií se seznámil s Cropatiem a obdržel jeho báseň. Baldi ji zařadil do části svého rukopisu,

9) Předmluva Ode de adventu Iesu Christi, Pragae: Georgius Daczicenus 1574, alb (za kopii tisku děkujeme Lence Veselé): „Huic exiguo munusculo adiunxi etiam officium Missae: quod symphonia 5 vocum, super quandam mutetam nuper composui: siquidem et poetica studia cum musicis optime coniunguntur: et tu non minus haec, quam illa, amas. Quare obnixe etiam atque etiam oro: ut utrumque munusculum, exiguum licet, ac levidense, grato benevoloque animo suscipere velis: et me iuvare et promovere non desistas. Alio tempore, dum maturuerit aetas: et si Musae magis favebunt meis coeptis: graviora, melioraque offerre conabor. Ad quae plurimum me excitabis: cum intellexero grato haec parta et rudia te accepisse animo."

10) Soupis těchto tisků viz Rukovět' 1 , s. 496-497.

11) Jeho itinerář je jen velmi stručně popsán v GRUNDMANN, Christian Wilhelm: Versuch einer Ucker-Märckischen Adels-Historie, Bd. 1, Christian Ragoczy, Prentzlau 1744, s. 183-184.

12) Christliche Betrachtung aller Gottes Heiligen und Gleubigen Pilgram- und Bürgerschafft. (Herzog August Bibliothek Wolfenbüttel, signatura Xa 1:1 [12], dále HAB). Viz BEPLER, Jill: Travelling and Posterity: the Archive, the Library and the Cabinet, in: Grand Tour: Adeliges Reisen und Europäische Kultur vom 14. bis zum 18. Jahrhundert, Jan Thorbecke Verlag, Ostfildern 2005, s. 201.

13) BRAVI, Luigi: Epigrammi greci in un manoscritto di epigrammi di Bernardino Baldi, Studi umanistici Piceni, roč. 36, 2016, s. 205-206 (edice s italským překladem, dále BRAVI). Editor básně k osobě jejího autora podotýká, že se mu nepodařilo jej bliže identifikovat. 
v které shromáždil řecké a italské básně věnované Gioseffu Zarlinovi, ${ }^{14}$ významnému italskému skladateli a hudebnímu teoretikovi, kterého ještě v našem textu zmíníme v souvislosti s Cropatiovým tiskem mší (AD IOSEPHUM ZARLINUM CARMINA).${ }^{15}$ Cropatiova řecká báseň v Baldiho rukopisné sbírce opěvuje ve stylu humanistických oslavných textů hudbu jako velký boží dar, pojednává její blahodárné působení na člověka a oceňuje Zarlinův přínos hudbě a zpěvákům.

O Cropatiově cestě do Jeruzaléma máme zprávy z dochovaných cestovních deníků šlechtických dobrodruhů, žoldáků a cestovatelů Leopolda von Wedel (1544-1615) a Josta Fögelliho (1554-1607), oba českého studenta a hudebníka zmiňují. ${ }^{16}$ Součástí výpravy se stal nejspíše v květnu 1578 v Benátkách společně s Hansem von Arnim, s nímž snad předtím studoval v Padově, a s Jostem Fögellim. ${ }^{17}$ Členem výpravy byl také holandský lékař Bernardus Paludanus (1550-1633), jehož dochovaný památník také dokumentuje svými záznamy průběh cesty. ${ }^{18} \mathrm{Z}$ Benátek (kde Cropatius nechal vytisknout své mše, jak o tom ještě pojednáme níže) vyrazili cestovatelé lodí 22. června 1578 směrem na Kypr a pak dále přes Tripolis do Jaffy, kde přistáli 4. srpna. V Ramle se k výpravě přidal pozdější direktor a člen sboru defensorů stavovského povstání Kryštof z Fictumu. ${ }^{19}$ Čtyřicet osm dní od vyplutí z Benátek dorazili cestovatelé 8. srpna 1578 do Jeruzaléma. Tam absolvovali týdenní prohlídku svatých míst, zahrnující obvyklý program návštěvníků a poutníků. ${ }^{20}$ Skupina se pak rozdělila a šlechtici se svými průvodci pokračovali v cestě, zatímco Cropatius se spolu se třemi jezuity od výpravy oddělil 15./16. srpna a zůstal v Jeruzalémě, aby se věnoval hudbě a složil něco pro bratry v klášteře sv. Salvátora. ${ }^{21}$

14) B. Baldi je také autorem první biografie Gioseppe Zarlina. Srov. BALDI, Bernardino: Le vite de’ matematici: Edizione annotata e commentata della parte medievale e rinascimentale a cura di E. Nenci, F. Angeli, Roma 1998, s. 543-557.

15) BRAVI, op. cit. v pozn. 13, s. 200-201, 204-206.

16) Wedelův popis vydal BÄR, Max: Lupold von Wedel's Beschreibung, F. Hessenland, Stettin 1895 (dále BÄR), nověji o něm podrobně s prehledem starší literatury KOŚCIELNA, Joanna A.: Lupolds von Wedel Bericht von der Reise in den Nahen Osten (1578-1579). Teil I: Peregrinatio Hierosolymitana Leopoldi de Wedell, Stargardia, roč. X, 2015, s. 233-279 (dále KOŚCIELNA). O Cropatiovi s. 243, pozn. 84 a s. 254-255. Fögelliho popis cesty, zachovaný ve Fribourgu, popsal von DIESBACH, Max: Le pellegrinage en Terre-Sainte de Josse Voegeli 1578, Revue del histoire vaudoise, roč. 9, 1901 (dále DIESBACH). Rozšírený popis s ukázkami vydal KING, Norbert: Die „Pilgerfartt" des Freiburger Ritters Josef Fögelli (1578-1579), Freiburger Geschichtsblätter, roč. 86, 2009, s. 117186 (dále KING).

17) BÄR, op. cit. v pozn. 16, s. 62: „Zudem ist da ein Studente aus dem Lant zu Bemen, welcher auch zu Padua studeret, mit dem Dofnam Jurge genannt, der Zunam mir vorgessen. Derfultig handelt auch, dass er mit zok (1578, Mai, Juni)."

18) Nationale Bibliotheek van Nederland, Den Haag, signatura KW 133 M 63, obecně KOŚCIELNA, op. cit. v pozn. 16, s. 237 et passim upozorňuje na konkrétní zápisy.

19) Mezi houfy lotrův se pustili... České cestopisy o Egyptě 15.-17. století, ed. Lucie Storchová, SET OUT- Roman Míšek, Praha 2005, s. 224-227 (list Kryštofa Fictuma z Aleppa).

20) KING, op. cit. v pozn. 16, s. 128-129.

21) KING, op. cit. v pozn. 16, s. 131: ,vnnd liessen do die dry Jesuiter vnnd vnsser Gsellen ein, Jorgius Cropatius genannt, ein Böhem, welcher sagt, er welle ein monat oder etlich do blyben, dan er was ein Componist oder Musicus unnd wolt den Brüdren (des Salvatorklosters in Jerusalem) etwas machen" (fol. 86v). U Salvátora pobýval o dvacet let později, roku 1598, také Kryštof Harant z Polžic a Bezdružic, zpěv mnichů jej velmi zaujal 


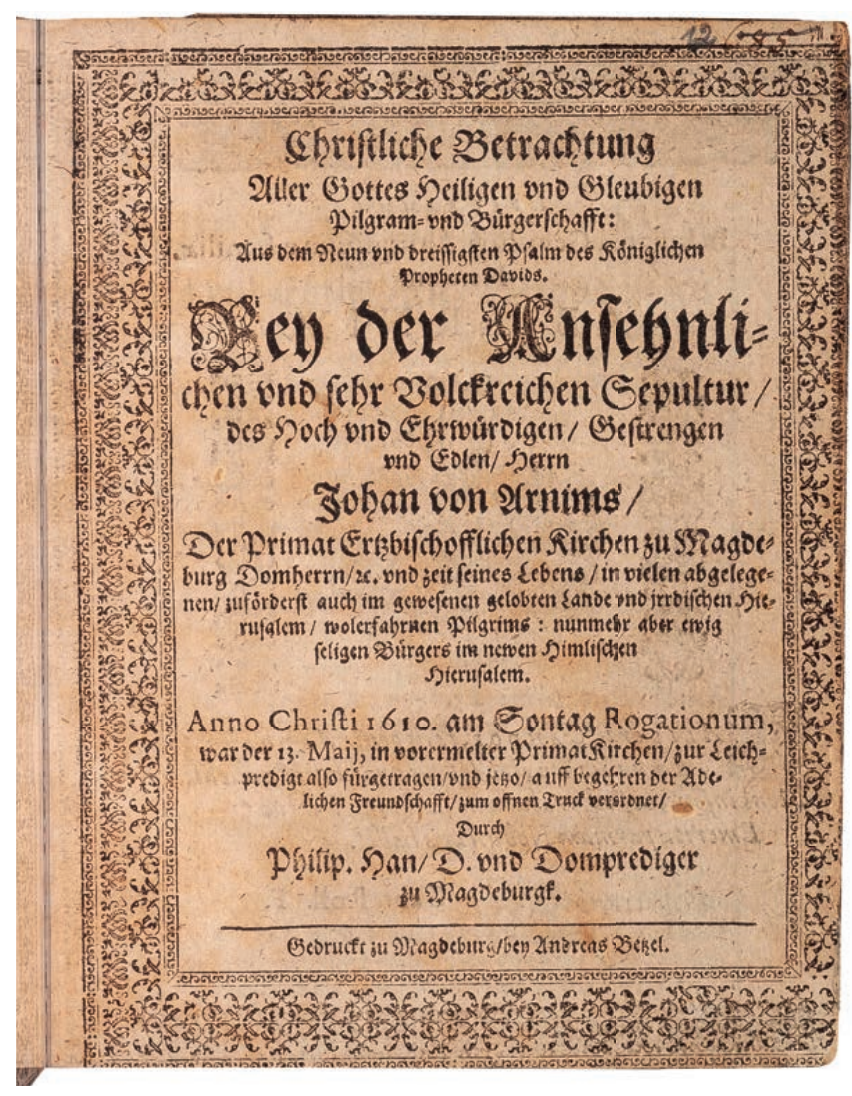

\section{Philipp Han: Christliche Betrachtung aller Gottes Heiligen und} Gleubigen Pilgram- und Bürgerschafft

Print / Tisk, Andreas Betzel, Magdeburg, 1610

Title page / Titulní list

Herzog August Bibliothek Wolfenbüttel, shelf mark / sign. Xa 1:1 (12)
V cestovních zprávách z Jeruzaléma se o Cropatiovi mluví jako o katolíkovi, který se tudíž neodmítl ve františkánském kostele vyzpovídat spolu s Fögellim a Hansem Sebaldem von Gemmingen. Ostatní členové výpravy, kteří byli luteráni, se pochopitelně zpovídat nechtěli. ${ }^{22}$ Dá se tedy předpokládat, že Cropatius v době svého pobytu v Itálii konvertoval. V Jeruzalémě se seznámil s Melétiem Pegasem, pozdějším alexandrijským patriarchou. Ten jej ve své latinské básni ocenil jako vynikajícího hudebníka a znalce jazyků. ${ }^{23}$ Jeho poetická chvála se zachovala ve dvou rukopisných verzích v kontextu dalších textů připomínajících Melétiův pobyt $\mathrm{V}$ Jeruzalémě, ${ }^{24}$ kam přijel roku 1579 v družině arcibiskupa Eugenia ze Sinaje na volbu patriarchy Sofronia IV.

Nadpis básně, který se dochoval v rukopise Ioanna Sakkéliona, vystihuje Cropaciovy hlavní kvality - totiž jako hudebníka a znalce tří svatých jazyků:

\section{Ad Georgium Copaccium (!) Polacum apprime doctum triplicique in genere linguarum} versatissimum, tum musicum ac poetam peritissimum. ${ }^{25}$

a tamní hudba mu dala podnět $\mathrm{k}$ tvorbě moteta na žalm 124, viz HARANT z POLŽIC a BEZDRUŽIC, Kryštof: Putování aneb Cesta z království českého, ed. Hana Bočková et al., Host, Praha - Brno 2017, s. 166 nn. a 294.

22) KOŚCIELNA, op. cit. v pozn. 16, s. 255.

23) Z rukopisu v knihovně grécisty Ioanna Sakkéliona vydal báseň Émile LEGRAND: Lettres de Mélétius Pigas, J. Maisonneuve, Paris 1902, s. 8, na s. IX předmluvy odkazuje také na její výskyt v rukopise univerzity v Tübingen, sign. Mb 10, s. 332 s nadpisem „Ad Georgium Cropacium Polacum poetam et musicum“. Tento rukopis zvaný „Le codex Vratislav" byl ve vlastnictví profesora řečtiny Martina Crusia, jenž texty opatřoval latinskými margináliemi, u naší básně čteme „Laus poetae“.

24) Např. báseň jeruzalémskému guardiánu Jeremiasi von Brixen na s. 330 tübingenského rukopisu.

25) Ad Georgium Cropacium Polacum poetam et musicum] Tübingenský rkp. 
Non tu pectus iners sine numine docte Georgi

Calliopes, Euterpes, Uraniesque decus.

Carmine tu, numerisque potens, ${ }^{26}$ non saeva ferarum

Pectora, sed poteris flectere corda hominum;

Corda hominum, superumque ${ }^{27}$ tibi Threicius 'O $\rho \phi \varepsilon \dot{s} \varsigma$

cedat, seque matre iam neget esse Dea. ${ }^{28}$

Další zprávy o Cropatiově osudu jsou nejisté. Je otázka, zda jej můžeme ztotožnit s alumnem olomoucké koleje, tehdy třicetiletým (podle této zprávy, pokud se opravdu jednalo o „našeho“ Cropatia, bychom mohli odhadovat, že se narodil kolem roku 1550), který byl vyloučen z koleje „propter liberius ingenium“ 20. května 1580 a žádal, aby se mohl do semináře vrátit. Víme, že Cropatius již dříve konvertoval a ve Svaté zemi se stýkal s jezuity, není tedy úplně vyloučeno, že mohl vstoupit do olomouckého semináře. Na jeho případ bylo pohlíženo mírně, protože obrátil na víru jakousi nekatolickou dámu a jeho protestantští rodiče jej po konverzi odmítli podporovat. Bylo mu tedy zajištěno ubytování u některého olomouckého měštana a malá finanční podpora, do semináře se však již vrátit nemohl. ${ }^{29}$

Podle Bohuslava Balbína byl Cropatius literárně činný i nadále, vydal prý své básně ještě v roce 1580, 1583 a 1585. ${ }^{30}$ Toto Balbínovo tvrzení, které později převzal i Cerroni, ${ }^{31}$ nelze nijak potvrdit ani vyvrátit, žádné tisky, které by pod jeho jménem byly v té době vydány, neznáme.

\section{Cropatius jako básník}

V literatuře se Cropatius profiloval jako básník. Kromě standardní latiny psal od dob svých studií básně i v řečtině a významný je také tím, že jako jediný náš předbělohorský humanista otiskl i vlastní básně psané hebrejsky. Jeho dochované básnické skladby patří do žánrů př́ležitostné a náboženské poezie. Co se latinské tvorby týče, můžeme zde mluvit o dobrém řemeslném zvládnutí veršové techniky a základních pravidel žánrů, přičemž používal prakticky pouze dva veršové rozměry - elegické distichon a sapfickou strofu. Cropatiovy řecké

26) potest] Tübingenský rkp.

27) supernumque] Tübingenský rkp.

28) Reprodukovaný text vychází z Legrandovy edice Sakkélionova rukopisu, různočtení v poznámkách jsou z tübingenského rukopisu Martina Crusia (viz pozn. 23).

29) THENIER, Augustin: Versuche und Bemühungen des heiligen Stuhles in den letzten drei Jahrhunderten die durch Ketzerei ... von ihm getrennten Länder des Nordens wieder mit der Kirche zu vereinen, Verlag der Karl Kollmann'schen Buchhandlung, Augsburg 1839, sv. 1-2, s. 137 cituje list papežského legáta Antonia Possevina z listopadu 1580 z Prahy: „Georgius Cropacius, Bohemus, 30, discessit 20 Maji 1580 ... Georgius autem Cropacius, nobilis Bohemus, cum propter liberius illius ingenium dimissus esset, ac vero me redeunte vehementer ursisset, ut iterum admitteretur in Seminarium, existimatum est, ut neque reciperetur, nec tamen omni praesidio destitutus relinqueretur, quod ob nobilitatem, et quia nobilem matronam Picardicam convertit, quodque ejus parentes haeretici nihil illi suppeditant, adjuvandus videretur. Itaque ad duos menses pensionem ei solvi apud civem Olomucensem unius talleri cum dimidio pro singulo mense, pecuniamque Patri Rectori Collegii reliqui, qua si vel is vel aliquis alius pergant in studiis et pietate, possint tantisper juvari, dum cum V. D. Ill[ustrissi]ma loqui potero."

30) BALBÍN, Bohuslav: Bohemia docta, Pars I., ed. K. R. Ungar, Pragae: Adamus Hagen 1776, s. 278.

31) Viz Rukovét' 1 , s. 497. 
a hebrejské verše na své zhodnocení teprve čekají. Oba tyto jazyky se sice v tiscích vyskytují variantně, řečtina však byla často prioritní a pro její znalost byl básník ceněn i v zahraničí, jak o tom svědčí jedna báseň dochovaná v rukopise.

První Cropatiovy verše byly vytištěny ve Vitenberku po zhruba dvouletém studiu v roce 1571. Napsal krátkou průvodní báseň v řecké a latinské verzi k náboženskému eposu Jana Felixe Chrudimského Historia Passionis. Řecká verze je zde, oproti obvyklému úzu, primární a na ni navazuje latinská parafráze. Po delší odmlce přispívá Cropatius na začátku roku 1574 do sborníku epicedií pro manželku Ernsta Albrechta Kindlera ze Zackensteinu, s jehož syny ve Vitenberku studoval. Na sborníku participovali i další čeští humanisté - Tomáš Mitis, Šimon Proxenus či Jakub Havlík z Varvažova. I zde prezentoval Cropatius napřed řeckou a pak latinskou variantu básně v poměrně velkém rozsahu třiceti jedna elegických distich.

Po návratu do Čech Cropatius ještě téhož roku participuje na dvou tiscích vydaných u Jiřího Nigrina (kde v té době vycházela víc než polovina básnické produkce), ${ }^{32}$ epithalamii v sapfické strofě přispívá do sborníku pro Kašpara Menšíka z Menštejna a Václava Havlíka z Varvažova. Zatímco v případě epithalamia pro Menšíka se jedná o dosti konvenční výtvor, v epithalamiu pro Havlíka z Varvažova nechává autor promlouvat postupně tři ctnosti spojené s manželstvím - zbožnost, svornost a trpělivost (Pietas, Concordia, Patientia). Není úplně vyloučeno, že jejich promluvy mohly být zhudebněny.

Ve svém pražském období, ohraničeném léty 1574-1575, vydal Cropatius několik samostatných drobných tisků a jednolistů. Jejich společným jmenovatelem jsou až na jednu výjimku básně náboženského obsahu, které věnoval svým mecenášům a vlivným měštanům či městským radám, od nichž bylo možné očekávat podporu.

Pravděpodobně nejstarším pražským Cropatiovým tiskem je Ode de adventu Iesu Christi pro Jiřího Mehla ze Střelic, kterou nechal vytisknout u Jiř́ho Jakubův Dačického. Všechny další tisky již svěřoval oficíně Jiřího Nigrina. Podle předmluvy začal Cropatius psát ódu o Vánocích 1573 (tento typ poezie býval obvyklým vánočním či novoročním dárkem), ale vydal ji až v průběhu roku 1574. Na titulním listu je vytištěna krátká hebrejská báseň „in Cristum Emmanuelem“, následuje latinská báseň o příchodu Krista v rozsahu třiceti šesti sapfických strof.

Onou výše zmíněnou výjimkou, na niž je třeba zvlášt upozornit, je jednolist s epicediem Jana Vartovského z Varty ${ }^{33}$ ve třech jazycích. K latině a řečtině přidává Cropatius poprvé také hebrejštinu. Zatímco řecké typy používali tiskaři v českých zemích už od padesátých let 16. století, Cropatiův jednolist je shodou okolností prvním dokladem užití hebrejských typů u nás, a to $\mathrm{v}$ tiskárně Jiř́ho Nigrina. ${ }^{34}$ Kromě znalosti jazyků demonstruje autor

32) ŠÍCHA, Vojtěch: Jazyková skladba pražské tiskařské produkce 16. století, Knihy a dějiny, roč. 25, 2018, č. 1-2, s. 58.

33) Jan Vartovský z Varty, nadaný pražský měštan, jenž překládal Starý Zákon z hebrejštiny, rukopis se však nedochoval, viz VOIT, Petr: Starý Zákon [heslo], in: Encyklopedie knihy, Libri, Praha 2006, s. 840. Ještě roku 1566 se někteří učenci snažili, nabádáni Janem Blahoslavem ke spěchu, preklad vydat (JIREČEK, Josef: Rukovět k dějinám literatury české do konce XVIII. věku: ve spůsobě slovnika životopisného a knihoslovného, B. Tempský, Praha 1875, s. 310.)

34) VESELÁ, Lenka: Hebrejská typografie v českých nežidovských tiskárnách 16. a 17. století, in: Hebrejský knihtisk v Čechách a na Moravě, Academia, Praha 2012, s. 165-176, zde s. 169. 
v jednolistu i formální básnické dovednosti - všechny tři jazykové verze obsahují v akrostichu jméno zemřelého. Jan Vartovský z Varty zemřel 3. července 1559, jednolist mohl být vydán k patnáctému výročí jeho úmrtí. Vzhledem k tomu, že epicedia byla vydávána obvykle nedlouho po smrti příslušné osoby, si můžeme klást otázku, co přimělo Cropatia, jenž byl v době Vartovského úmrtí ještě chlapcem, k opožděnému vydání epicedia. Více nám nenapoví ani epitaf Vartovského z pera Tomáše Mitise, který je na jednolistu také otištěn. Můžeme se domnívat, že se Cropatius chtěl přihlásit k odkazu Jana Vartovského z Varty jako vzdělance, jenž ovládal tři svaté jazyky a překládal z nich do češtiny. Epicedium je uvedeno zamyšlením nad krátkostí lidského života, který bývá někdy náhle ukončen, jako tomu bylo u Vartovského. V jádru básně stojí chvála jeho znalostí hebrejštiny, řečtiny a latiny, v závěru předpovídá Cropatius Vartovskému věčný život, ale také věčnou slávu. Snad měl být jednolist zaštítěný Mitisovou autoritou jakýmsi doporučením autora stejnojmennému synovi Jana Vartovského, jenž zdědil (nepochybně zajímavou) knihovnu svého otce včetně rukopisů jeho přkkladů. ${ }^{35}$

Ve volbě námětů a forem je jasně patrné Cropatiovo vitenberské vzdělání, které poznamenalo už i starší generaci našich humanistů, rovněž vitenberských absolventů (Matouš Collinus, Tomáš Mitis aj.). ${ }^{36} \mathrm{~S}$ náboženskou poezií se zde velmi často pojila hudba. Velmi konkrétně se jeho vitenberská inspirace projevuje v případě Cropatiovy básnické skladby Oda de angelis. Ta je silně ovlivněna stejnojmennou ódou Philippa Melanchthona, která byla mnohokrát zhudebněna v originále i v německém překladu Paula Ebera. ${ }^{37} \mathrm{~V}$ některých pasážích používá Cropatius původní Melanchthonovo dílo jako rámec, v němž obměňuje slova a slovní spojení. Jako prŕklad uved’me jednu sloku:

Melanchthon:

Interim sed nos tegit Angelorum

Quae ducem Christum sequitur, caterva,

Atque grassantis reprimit cruenta

Arma Draconis.

\section{Cropatius:}

Turma sanctorum vigil Angelorum

Hostis a pravi metuere rictu

Servat et diri reprimit cruenta

Arma Draconis.

Vitenberskou inspiraci mohla mít také Cropatiova báseň Cymba Christi, v níž autor rozvíjí motiv z evangelia sv. Matouše 8, 18-21 a líčí Kristovu církev jako lod’ku zmítající se v bouři.

35) ADAM z VELESLAVÍNA, Daniel: Kalendář historický, Praha: Daniel Adam 1590, s. 303.

36) O vitenberské náboženské poezii viz KIPF, Klaus: Geistliche Dichtung Wittenberger Humanisten in der ersten Hälfte des 16. Jahrhunderts - Zeugnis einer Devotionspraxis?, in: Wie fromm waren die Humanisten?, eds. Berndt Hamm - Thomas Kaufmann, Harrassowitz Verlag, Wiesbaden 2016, s. 261-285.

37) Tamtéž, s. 271-273. 
Tento motiv vysvětluje i v předmluvě, dedikované lounské městské radě. Srovnáme-li tuto skladbu se stejnojmennou básní Johanna Maiora, která je navíc psána také elegickým distichem, ${ }^{38}$ zjistíme však překvapivě velké rozdíly, zejména v použití antické mytologie, která u Cropatia dominuje - na scénu kromě Aiola, vládce větrů, uvádí také Scyllu a Charybdu. Téma „lod'ky církve“ bylo v té době natolik rozšířené, že autor mohl mít i jiné vzory, například básníka vídeňské univerzity Veita Jacobaea, jenž hexametry na stejné téma věnoval Antonínu Brusovi z Mohelnice u př́ležitosti jeho jmenování pražským arcibiskupem. ${ }^{39}$

Pravděpodobně ani sám Cropatius nepovažoval básnickou tvorbu za svou hlavní kvalitu a jeho básnické pokusy je třeba chápat v souvislosti s jeho curriculem jako drobná dílka, která mu sloužila k podpoře při hledání uplatnění a získávání nových přátel. Pro zkoumání jeho zahraničních kontaktů jsou pozoruhodné rukopisné příležitostné básně, které se v souvislosti s ním zachovaly v cizině, a není vyloučeno, že budou postupem času nalezeny další.

\section{Cropatius a hudba}

Tisk polyfonních mší, který na české poměry zcela atypicky vydal Jiří Cropatius v Benátkách, je zmiňován zřejmě poprvé v katalogu produkce tiskárny Angela Gardana z roku 1591, ${ }^{40}$ a to velmi stručně takto: Messe di Georgio Cropatio A 5. et 6. (myšleno tedy mše pro pět a šest hlasů). ${ }^{41}$ Originál tisku musel vidět Johann Clessius, který v soupisu Unius saeculi, eiusque Virorum litteratorum ... elenchus consummatissimus uvádí jeho detailní název, resp. opis titulní strany. ${ }^{42}$ Publicista, vydavatel a editor řady soupisových děl vydaných na začátku 17. století Georgius Draudius ${ }^{43}$ zřejmě vyšel z tohoto katalogu tisků Johanna Clessia, když do jedné ze svých stěžejních prací Bibliotheca classica sive catalogus officinalis z roku $1625^{44}$ zařazuje Cropatiovo dílo, podle něho vydané roku 1548. To je bezpochyby omyl, který tímto tiskem vstoupil do další literatury až do dnešní doby. Cropatiův tisk uvádí v kapitole Libri musici, v části označené jako Missae, kde ho cituje jako: Georg. Cropatii Missarum Tomus

38) MAIOR, Johannes: Psalmi duo CXXXI. et CXXV. explicati carmine elegiaco. Item, Cymba Christi, Wittenberg: s. t. 1556, A3a-A5a (VD16 B 3443). O deset let později vyšel tisk Johanna BUNTSCHENIA Cymba Christi, quae est imago ecclesiae, Wittenberg: Schwenck 1566 (VD16 B 9785). Exemplář HAB A: 36.3 Poet. (35).

39) JACOBAEUS, Vitus - LACTANTIUS CODICIUS, Joannes: Carmen in consecrationem et inaugurationem reverendissimi principis D.D. Antonij de Muglitz, Wien: Hofhalter 1561. Rukovět'1, s. 232-233.

40) Srov. AGEE, Richard J.: The Gardano Music Printing Firms, 1569-1611, University of Rochester Press, Rochester 1998, s. 221, 363, 392, Appendix II. A - Annotation of the 1591 Gardano Booklist a Appendix II. B, Chronological Ordering of the 1591 Gardano Booklist by Date of Publication (dále AGEE).

41) THIBAULT, Geneviève: Deux catalogues de libraires musicaux: Vincenti et Gardane (Venise 1591), Revue de musicologie, roč. 10, 1929, č. 32, s. 177-183 a roč. 11, 1930, č. 33, s. 7-18; MISCHIATI, Oscar: Indici, cataloghi e avvisi degli editori e librai musicali italiani dal 1591 al 1798, Olschki, Firenze 1984.

42) CLESSIUS, Johann: Unius saeculi, eiusque Virorum literatorum monumentis ab Anno Dom. 1500 ad 1602, Elenchus consumatissimus, Frankfurt: Ioannes Saurius 1602, s. 396.

43) Draud Georg (1573-1630); Draudius Georgius; Draut Georg, srov. kupř. GREEN, Lawrence D. - MURPHY, James Jerome: Renaissance Rhetoric Short-title Catalogue 1460-1700, Ashgate Publishing, Farnham 2006, s. 171.

44) Srov. DRAUDIUS, Georgius: Bibliotheca classica sive catalogus officinalis in quo singuli singularum facultatum ac professionum libri, qui in quavis fere lingua extant quique intra hominum propemodum memoriam in publicum prodierunt secundum artes et disciplinas ... recensentur, Francofurti ad Moenum: Balthasar Ostern 1625, s. 742. 
primus, 5. vocum, iuxta dodecachordi modos, Dorii scilicet, Hypodorii E Lidii compositus, Venet. 1548. in $4 .{ }^{45}$ Především z této práce, korigované někdy i náhledem do Clessia, pak vycházela řada encyklopedistů od 18. do 20. století. ${ }^{46}$

Kupř́kladu autor prvé německé hudební encyklopedie Musicalisches Lexikon oder Musicalische Bibliothec (1732) Johann Gottfried Walther vychází v hesle o Jiřím Cropatiovi z Draudiovy práce, kterou př́mo cituje. Zachovává i jeho špatné vročení Cropatiova tisku (1548). ${ }^{47} \mathrm{Na}$ Johanna Clessia se naopak odvolává po necelých sto letech po Waltherovi Gottfried Johann Dlabacz (1812), který opakuje informaci o Cropatiově tisku a shrnuje dosavadní nečetné zmínky o něm. ${ }^{48}$ I další hudebně soupisová a lexikografická díla 19. století Walthera či Dlabacze nepřekonávají, nebot' jim pro to chybí nové informace či zjištění. ${ }^{49}$ Vrcholné hudebně lexikografické dílo konce 19. století Roberta Eitnera Biographisch-Bibliographisches Quellen-Lexikon der Musiker tak logicky jen střídmě konstatuje ve svém 5. díle vydaném v Lipsku v roce 1901, že od dob Draudia opakují všechny encyklopedie o Jiř́m Cropatiovi to samé. Zároveň konstatuje, že stále citované vydání Cropatiových mší nebylo do doby vydání jeho lexika nalezeno. ${ }^{50}$ Nezaznamenal tak, a asi to ani nebylo vzhledem k okrajovému významu tohoto hesla v Eitnerově rozsáhlém lexiku možné či podstatné, že deset let před ním se nová informace k dílu Jiřího Cropatia objevila v soupisové práci Emila Bohna, který zpracoval hudební rukopisy 16. a 17. století z fondu

45) Tamtéž, s. 1222.

46) Česká muzikologická literatura 20. století zmiňuje Jiřího Cropatia také stále stejně opakovanou informací o jeho benátském tisku, takže nemá smysl uvádět její přehled. Za všechny tituly jmenujme alespoň Česká polyfonní tvorba. Výběr vícehlasých děl českého původu z XVI. a XVII. století, ed. Jitka Sní̌ková, SNKLHU, Praha 1958, s. 14; ŠTĚDROŇ, Bohumír: Cropatius, Jiř́ [heslo], in: Československý hudební slovník osob a institucí, I., SHV, Praha 1963, s. 172; MACEK, Petr: Cropatius, Jiř́ [heslo], in: Český hudební slovník osob a institucí, dostupné z: http://ceskyhudebnislovnik.cz/slovnik/index.php?option=com_mdictionary\&task=record.record_detail\&id=6345 [cit. 6. 4. 2020].

47) WALTHER, Johann Gottfried: Cropatius (Georgius) [heslo], in: Musicalisches Lexikon oder Musicalische Bibliothec, Wolfgang Deer, Leipzig 1732, s. 193.

48) DLABACZ, Gottfried Johann: Kropácz Georg [heslo], in: Allgemeines historisches Künstlerlexikon für Böhmen und zum Theil auch für Mähren und Schlesien, Zweiter Band, J-K, Gottlieb Haase, Praha 1815, sl. 139-140.

49) Kupř. GERBER, Ernst Ludwig: Cropatius (Georgius) [heslo], in: Neues historisch-biographisches Lexikon der Tonkünstler: welches Nachrichten von dem Leben und den Werken musikalischer Schriftsteller, berühmter Komponisten, Sänger, Meister auf Instrumenten, kunstvoller Dilettanten, Musikverleger, auch Orgelund Instrumentenmacher, älterer und neuerer Zeit, aus allen Nationen enthält, A. Kühnel, Leipzig 1812, sv. 1, sl. 822; FÉTIS, François-Joseph: Cropatius (George) [heslo], in: Biographie universelle des musiciens et bibliographie générale de la musique, sv. 3, Leroux, Bruxelles 1836, s. 222; BECKER, Carl Ferdinand, in: Die Tonwerke des XVI. und XVII. Jahrhunderts oder systematisch-, chronologische Zusammenstellung der in diesen zwei Jahrhunderten gedruckten Musikalien, Erns Fleischer, Leipzig 1847 uvádí dokonce Cropatiův tisk dvakrát, nejdřive k roku 1548 pod jménem Cropatius G. (sl. 4), následně pak k roku 1578 (sl. 8) pod jménem Kropacz G; Cropatius, Georg [heslo], in: Musikalisches Conversations-Lexikon. Eine Encyklopädie der gesammten musikalischen Wissenschaften. Für Gebildete aller Stände, eds. Hermann Mendel - August Reissmann, sv. 2, Robert Oppenheim, Berlin 1872, s. 27: uvádí obě data, tedy „Venedig 1548 und 1578.“

50) EITNER, Robert: Kropácž (Cropatius), Georg [heslo], in: Biographisch-Bibliographisches Quellen-Lexikon der Musiker und Musikgelehrten, sv. 5, Breitkopf \& Haertel, Leipzig 1901 (dále EITNER), s. 458. 
městské knihovny ve Vratislavi. Bohn totiž v tomto fondu podchytil i jednu pětihlasou mši s atribucí Jiř́mu Cropatiovi. ${ }^{51}$

Emil Bohn zahrnul do svého katalogu vratislavských hudebních rukopisů také kolekci velice zajímavých a pro dějiny hudební kultury v Čechách podnětných souborů hlasových knih. Řada z nich totiž dokládá skutečnou blízkost a propojenost hudebního dění ve Vratislavi a v českých městech na konci 16. století. Jsou v nich totiž zapsány i skladby autorů, kteří žili a působili v Praze, především při císařském dvoře, a také osobitá generace skladatelů pocházejících ze severních oblastí Čech, zvláště jazykově německých. ${ }^{52}$ Jedním z nich je rukopis, který Bohn označuje číslem 99.53 Již v době vzniku katalogu byly dochovány jen dvě hlasové knihy - Alt a Vagans / Quinta vox - z původního souboru nejspíše šesti svazků. Rukopis, rozdělený na dvě části, obsahuje $14+21$ zhudebnění mešního ordinaria či alespoň několika jeho částí. První část rukopisu obsahuje většinou šestihlasé mše, druhá mše pro pět hlasů. Mezi autory dominují skladatelé rudolfínského okruhu (Philippe de Monte 8 mší, Alexander Utendal 1 mše, Jacob Regnart 2 mše, Johan de Cleve 1 mše, Alessandro Orologio 1 mše, Tiburzio Massaini 1 mše, Georgius Flori 1 mše), početně je zastoupen středoevropsky nejpopulárnější skladatel Orlando di Lasso ( 8 mší), dvěma skladbami je v rukopisu uveden Jacobus Handl Gallus; zastoupeni jsou i skladatelé, kteři se profesně uplatnili v severních Čechách, Slezsku a Lužici (Johannes Nucius 2 mše, Michael Hess 2 mše, Christophorus Köckritz 1 mše, Gregor Langius 1 mše). Rukopis jedinečně zachycuje i skladby v podstatě neznámého a jinde nedoloženého Konráda Lehera (Conrad Leherius 1 mše), který zřejmě pocházel z bavorského Volkachu, ${ }^{54}$ a jeho známějšího krajana Thomase Elsbetha (Authore Thoma Helsbetho Franco, 1 mše), který se sice narodil v bavorském Neustadtu u Coburgu, ale žil a pracoval ve Frankfurtu nad Odrou, a dokonce i přímo ve Vratislavi. ${ }^{55}$

Rukopis vznikal postupně, jak je patrné z př́pisů na konci některých mší druhé části rukopisu, která zachycuje pětihlasé mše. Data, jimiž písaři dokládali dobu dokončení zápisu, se pohybují od 10. dubna 1595 (5. mše, Orlando di Lasso, Missa s. Credidi) ${ }^{56}$ do 21., resp.

51) BOHN, Emil: Die Musikalische Handschriften des XVI. und XVII. Jahrhunderts in der Stadtbibliothek zu Breslau, Ein Beitrag zur Geschichte der Musik im XVI. und XVII. Jahrhundert, Hainauer, Breslau 1890 (dále BOHN), s. 111$112,236,334$, „Georg. Cropatij. Missa 5v“. V indexu skladeb na s. 236 uvádí Bohn Cropatiovu mši v oddílu „Missa / 5v." stručným notovým incipitem altového hlasu vyjádřeným pomocí písmen: „99 B 21. Cropatius (A: - - - a d d h g d d c b a d d ch cis d cis d)".

52) DANĚK, Petr - BAŤA, Jan: Numero Arithmetico notata Series officiorum pro Choro Musico Ustensi (1588) aneb pramen polyfonie plný překvapení, Musicologica Istropolitana, roč. X-XI, 2011-2012, s. 45-67.

53) BOHN, s. 111-112. Popis rukopisu, který řadí mezi důležité prameny $\mathrm{k}$ hudbě skladatelů rudolfínského okruhu, uvádí také COMBERIATI, Carmelo Peter: Late Renaissance Music at the Habsburg Court. Polyphonic Settings of the Mass Ordinary at the Court of Rudolf II (1576-1612), Gordon and Breach Science Publishers, New York 1987, s. 225.

54) LEHER, Konrad, Volcacensis. Srov. EITNER, op. cit. v pozn. 50, sv. 6, 1902, s. 117, dále http://loci.gwi.uni-muenchen.de/Qp/Musikalische_Tätigkeit=Komponist [cit. 6. 4. 2020].

55) BIRKENDORF, Rainer: Elsbeth, Thomas [heslo], in: Die Musik in Geschichte und Gegenwart, Ludwig Finscher (Hrsg.), Zweite Ausgabe, Personenteil, Band 4, Bärenreiter/Metzler, Kassel u. a. 2000.

56) Názvy či označení mší zachycených v rukopisu Bohn 99 vycházejí v našem textu z tvaru, který je v tomto rukopisu použit. Zdůrazňujeme to proto, nebot' některé známější, resp. ve své době rozšířené mše, které byly zapsány i do tohoto rukopisu, nalezneme v jiných dobových pramenech s variantními podobami názvů. 
26. března roku 1600 (19. mše, Georgius Florius, Missa s. Come la turturelle). Cropatiova mše je zapsána jako poslední, tedy 21. v pořadí. Je uvedena pouze názvem Missa bez odkazu na předlohu, jak je tomu u většiny ostatních mešních ordinarií v rukopisu. Lze z toho proto usuzovat, že se nejednalo o parodickou mši. V zápisu zpěvního hlasu ve svazku Quinta vox je mše uvedena jako Missa a 5 Georgio Cropatio Authore, Cantus Secundus, ve svazku Altus Missa quinque Vocum Georgii Cropacii. Jak je patrné z poznámek v průběhu mše, základní obsazení bylo pětihlasé, Pleni sunt coeli bylo pouze tříhlasé a závěrečné Agnus Dei (AD) naopak šestihlasé. I když se dochovaly pouze dva hlasy z pěti a tím pádem lze těžko posoudit skutečné kompoziční kvality skladby, můžeme z dochovaných hlasů určit modus Cropatiovy mše. Je jím dórský modus, tedy týž, v jakém byla jedna ze mší benátského tisku.

Cropatiova mše ve vratislavském rukopisu neobsahuje Credo $(\mathrm{Cr})$. Vynechání této části ordinaria či i několika dalších není v tomto pramenu výjimečným. Písař, resp. pořizovatel či uživatel tohoto souboru polyfonních mešních ordinarií zapsal u některých mší jen některé části, většinou Kyrie (K) a Gloria (Gl), což souvisí s tradicí určitého typu tzv. Kurzmesse neboli Missa brevis, která se uplatňovala především v protestantské tradici. ${ }^{57}$ Zápis Cropatiovy mše, jak vyplývá z výše uvedeného, byl pořízen až po březnu roku 1600. Je tedy evidentní, že v té době měl písař vratislavského rukopisu k dispozici předlohu mše. Opis je proveden pečlivě, což je patrné i z toho, že je v této mši (není ale v rukopise jediná!) řada znamínek, které jednoznačně člení text pod notové úseky. To není v praxi středoevropských rukopisů, do kterých byl zapisován užívaný repertoár vokální polyfonie, až tak běžné. Často je to znakem toho, že předlohou mohl být i tisk. At již měl písař vratislavského rukopisu jakoukoliv předlohu, je doložitelné, že Cropatiova mše byla užívána či alespoň známa v kulturním prostoru Slezska kolem roku 1600. Dochované a Bohnem evidované vratislavské rukopisy jsou vzácným dokladem šiřky repertoáru, který byl na přelomu 16. a 17. století aktuální. A Cropatiova mše do tohoto zvláštního generačního, národnostního a stylového spektra zajímavě zapadá.

\section{Obsah a struktura vratislavského rukopisu Bohn $99^{58}$}

Následující tabulka přehledně shrnuje důležité informace k rukopisu Bohn 99. V prvém sloupci uvádíme číslo skladby a folia, na kterých se v rukopise nachází. Druhý sloupec uvádí jméno autora zapsané mše (moteta) podle př́ípisů v dochovaných hlasových knihách. Třetí sloupec obsahuje název př́slušné mše opět podle rukopisu a v posledním sloupci najdeme kompletní hlasové obsazení a všechny důležité marginálie, které jsou v rukopisu zapsány. Pokud nejsou v tomto sloupci uvedeny zkratkou zhudebněné částí mešního ordinaria, pak je zapsáno kompletně.

57) KAST, Paul: Die mehrstimmige Messe [heslo], in: Musikalische Gattungen in Einzeldarstellungen, Band 2: Die Messe, Deutscher Taschenbuch Verlag und Bärenreiter Verlag, 1985, s. 50-51 aj.; MORAWSKA, Katerzyna: The History of music in Poland: The Renaissance, Sutkowski Edition Warsaw, Warszawa 2002, s. 148 ad.

58) Rukopis Bohn 99 je v současné době stejně jako většina vratislavských hudebních rukopisů zachycených v Bohnově katalogu uložen v Berlíně: Staatsbibliothek zu Berlin - Preußischer Kulturbesitz, http://www. staatsbibliothek-berlin.de 


\begin{tabular}{|c|c|c|c|}
\hline $\begin{array}{l}\text { Číslo skladby podle } \\
\text { rkp. / folia Altus / } \\
\text { Quinta vox }\end{array}$ & Autor & $\begin{array}{l}\text { Název skladby podle } \\
\text { rukopisu }\end{array}$ & $\begin{array}{l}\text { Počet hlasů / mešní části / } \\
\text { poznámky, dobové prípisy Altus } \\
\text { / Quinta vox }\end{array}$ \\
\hline $1 / 1^{r}-4^{r} / 1^{r}-3^{r}$ & Philippe de Monte & Missa & 6 \\
\hline $2 / 5^{r}-8^{v} / 4^{r}-7^{r}$ & $\begin{array}{l}\text { Jacobus Handl } \\
\text { Gallus }\end{array}$ & $\begin{array}{l}\text { Missa s. Elisabeth } \\
\text { Zachariae }\end{array}$ & $6 / \mathrm{Ky}-\mathrm{Gl}-\mathrm{Cr}$ \\
\hline $3 / 8^{v}-10^{r} / 7^{r}-8^{v}$ & $\begin{array}{l}\text { Jacobus Handl } \\
\text { Gallus }\end{array}$ & $\begin{array}{l}\text { Missa s. Locutus est } \\
\text { Dominus ad Moysen }\end{array}$ & $\begin{array}{l}\text { 6/Ky }-\mathrm{Gl} \\
\text { Q.v.: Secundus Tenor }\end{array}$ \\
\hline $4 / 10^{v}-12^{r} / 8^{v}-10^{r}$ & \begin{tabular}{|l|} 
Alexander \\
Utendal \\
\end{tabular} & Missa s. Surge propera & $6 / \mathrm{Ky}-\mathrm{Gl}$ \\
\hline $\begin{array}{l}5 / 12 b_{i s}^{r}-15^{v} / \\
11^{r}-15^{r}\end{array}$ & Philippe de Monte & $\begin{array}{l}\text { Officium s. Nasce la } \\
\text { pena mia }\end{array}$ & 6 \\
\hline $6 / 16^{r}-20^{v} / 15^{v}-19^{r}$ & Michael Hess & $\begin{array}{l}\text { Missa s. Usquequo } \\
\text { Domine }\end{array}$ & $\begin{array}{l}6 \\
\text { Q.v.: Secundus Tenor }\end{array}$ \\
\hline $7 / 21^{r}-27^{r} / 19^{v}-24^{v}$ & Orlando di Lasso & Missa s. Si me tenes & 6 \\
\hline $8 / 27^{v}-33^{r} / 25^{r}-29^{v}$ & Orlando di Lasso & Missa s. In principio & 6 \\
\hline $\begin{array}{l}9 / 33^{v}-40^{r} / \\
30^{r}-35^{v}\end{array}$ & Orlando di Lasso & $\begin{array}{l}\text { Missa s. } \\
\text { Congratulamini }\end{array}$ & 6 \\
\hline $\begin{array}{l}10 / 41^{r}-45^{v} \\
45^{v}-46^{v} / 36^{r}-40^{r} \\
40^{v}-41^{v}\end{array}$ & Philippe de Monte & $\begin{array}{l}\text { Missa s. Si ambulavero } \\
\text { / moteto Si } \\
\text { ambulavero, vivificabis } \\
\text { me / 2. pars Illumina } \\
\text { oculos meos }\end{array}$ & $\begin{array}{l}6 \\
\text { Q. v.: Altus } 2\end{array}$ \\
\hline $\begin{array}{l}11 / 47^{r}-52^{v} / \\
42^{r}-47^{v}\end{array}$ & Jacobus Regnart & Missa Quodlibetica & $\begin{array}{l}6 \\
\text { Q. v.: Secundus Altus }\end{array}$ \\
\hline $\begin{array}{l}12 / 53^{v}-59^{r} / \\
48^{v}-53^{r}\end{array}$ & $\begin{array}{l}\text { Johannes } \\
\text { de Cleve }\end{array}$ & $\begin{array}{l}\text { Missa s. Dum transisset } \\
\text { sabbathum }\end{array}$ & 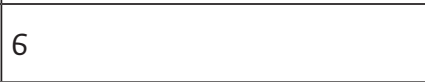 \\
\hline $\begin{array}{l}13 / 59^{v}-61^{r} / \\
53^{v}-55^{r}\end{array}$ & $\begin{array}{l}\text { Thomas } \\
\text { Helsbethus }\end{array}$ & $\begin{array}{l}\text { Missa s. Domine quid } \\
\text { multiplicati sunt }\end{array}$ & $\begin{array}{l}\text { 6/K-Gl } \\
\text { A, Q. v.: Authore Thoma } \\
\text { Helsbetho Franco } \\
\end{array}$ \\
\hline $\begin{array}{l}\text { 14/62r / } \\
\text { Q.v. neobsahuje }\end{array}$ & Orlando di Lasso & Missa s. O passi sparsi & $4 / \mathrm{K}-\mathrm{Gl}$ \\
\hline $66^{r} / 56^{r}$ & & & $\begin{array}{l}\text { A., Q. v.: Sequntur Missae } \\
\text { quinq[ue] vocum A }\end{array}$ \\
\hline $1 / 67^{r}-68^{v} / 57^{r}-58^{v}$ & & $\begin{array}{l}\text { Missa s. Transeunte } \\
\text { Domino }\end{array}$ & $\begin{array}{l}\text { 5/ K-Gl } \\
\text { Q. v.: Missa ad imitationem } \\
\text { Transeunte Domino }\end{array}$ \\
\hline $2 / 69^{r}-73^{v} / 59^{r}-63^{r}$ & Johannes Nucius & Missa s. Vestina colli & 5 \\
\hline $3 / 74^{r}-76^{v} / 65^{r}-66^{v}$ & Gregorius Langius & $\begin{array}{l}\text { Missa s. In dieser } \\
\text { weiten Welt }\end{array}$ & $\begin{array}{l}5 \text { / K-Gl } \\
\text { Q. v.: Sequntur Missa super } \\
\text { suavissimam Cantiunculam } \\
\text { In dieser weiten Welt. Authore } \\
\text { Gregorio Langio à } 5\end{array}$ \\
\hline $\begin{array}{l}4 / 77^{r}-80^{v} / \\
66^{v}-69^{v}\end{array}$ & $\begin{array}{l}\text { Christophorus } \\
\text { Köckritz }\end{array}$ & $\begin{array}{l}\text { Missa s. Gregorii } \\
\text { Langii motetam: Tota } \\
\text { pulchra es }\end{array}$ & $\begin{array}{l}5 \\
\text { Q. v.: Missa à } 5 \text { super suavissimam } \\
\text { motetam Gregorii Langii Tota } \\
\text { pulchra es, Secundus Tenor }\end{array}$ \\
\hline
\end{tabular}




\begin{tabular}{|c|c|c|c|}
\hline $\begin{array}{l}\text { Číslo skladby podle } \\
\text { rkp. / folia Altus / } \\
\text { Quinta vox }\end{array}$ & Autor & $\begin{array}{l}\text { Název skladby podle } \\
\text { rukopisu }\end{array}$ & $\begin{array}{l}\text { Počet hlasů / mešní části / } \\
\text { poznámky, dobové př́pisy Altus } \\
\text { / Quinta vox }\end{array}$ \\
\hline $5 / 81^{r}-84^{r} / 70^{r}-73^{r}$ & Orlando di Lasso & Missa s. Credidi & \begin{tabular}{|l|}
5 \\
1595. 10 Aprilis \\
Q. v.: Finis. Anno 1595. 10 Aprilis.
\end{tabular} \\
\hline $6 / 84^{v}-90^{r} / 73^{v}-77^{r}$ & Jacobus Regnart & Missa & $5-\mathrm{AD} 6$ \\
\hline $\begin{array}{l}7 / 90^{v}-94^{v} / \\
77^{v}-80^{v}\end{array}$ & Orlando di Lasso & $\begin{array}{l}\text { Missa s. Sydus ex claro } \\
\text { neniens Olympus }\end{array}$ & 5 \\
\hline $8 / 95^{r}-99^{r} / 81^{r}-84^{r}$ & $\begin{array}{l}\text { Alexandro } \\
\text { Orologio }\end{array}$ & $\begin{array}{l}\text { Missa s. Quando fra } \\
\text { bianche perle }\end{array}$ & $\begin{array}{l}5 \\
\text { Q.v.: } 2 \text { Tenor }\end{array}$ \\
\hline $\begin{array}{l}9 / 99^{r}-103^{v} / \\
84^{v}-89^{r}\end{array}$ & Conrad Leherus & $\begin{array}{l}\text { Missa s. Hispanum ad } \\
\text { coenam }\end{array}$ & $\begin{array}{l}5 \\
\text { A: Authore Conrado Lehero } \\
\text { Volcacensi Franco } \\
\text { Q. v.: 2. Altus }\end{array}$ \\
\hline $\begin{array}{l}10 / 103^{v}-108^{r} / \\
89^{r}-93^{v}\end{array}$ & Tiburtio Massaini & $\begin{array}{l}\text { Missa super } \\
\text { Hypodorium }\end{array}$ & $\begin{array}{l}5 \\
\text { Q.v.: } 2 \text { Tenor }\end{array}$ \\
\hline $\begin{array}{l}11 / 108^{\mathrm{r}}-111^{v} / \\
93^{v}-96^{v}\end{array}$ & Philippe de Monte & Missa & $\begin{array}{l}5 \\
\text { A: Altus } \\
\text { Q.v.: 2dus Tenor }\end{array}$ \\
\hline $\begin{array}{l}12 / 111^{v}-115^{r} / \\
96^{v}-99^{v}\end{array}$ & Philippe de Monte & Missa VII toni & $\begin{array}{l}5 \\
\text { A: Altus } \\
\text { Q.v.: } 2 \text { Tenor } \\
\end{array}$ \\
\hline $\begin{array}{l}13 / 115^{r}-118^{v} / \\
100^{r}-103^{r}\end{array}$ & Philippe de Monte & Missa & $\begin{array}{l}5 \\
\text { A: Altus } \\
\text { Q. v.: } 2 \text { Tenor }\end{array}$ \\
\hline $\begin{array}{l}14 / 118^{v}-122^{r} / \\
103^{r}-105^{v}\end{array}$ & Philippe de Monte & Missa & \begin{tabular}{|l|}
5 \\
Q. v.: 2 Tenor
\end{tabular} \\
\hline $\begin{array}{l}15 / 122^{r}-126^{r} / \\
106^{r}-109^{r}\end{array}$ & Orlando di Lasso & $\begin{array}{l}\text { Missa s. Le Berger et la } \\
\text { Bergere }\end{array}$ & $\begin{array}{l}5 \\
\text { Q. v.: } 2 \text { Tenor }\end{array}$ \\
\hline $\begin{array}{l}16 / 126^{v}-130^{v} / \\
109^{v}-113^{r}\end{array}$ & Orlando di Lasso & Missa s. Ite ime dolenti & $\begin{array}{l}5 \\
\text { Q. v.: Tenor } 2 \\
\end{array}$ \\
\hline $\begin{array}{l}17 / 131^{r}-135^{\vee} / \\
113^{r}-117^{r}\end{array}$ & Horatio Vecchi & $\begin{array}{l}\text { Missa s. Se desio } \\
\text { fuggier }\end{array}$ & 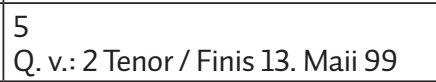 \\
\hline $\begin{array}{l}18 / 135^{v}-139^{r} / \\
117^{v}-120^{v}\end{array}$ & Michael Hess & $\begin{array}{l}\text { Missa s. Litaniam } \\
\text { b. M. V. Constantii } \\
\text { Portae }\end{array}$ & $\begin{array}{l}5 \\
\text { A: Finis } 28 \text { Maii Ao. } 99\end{array}$ \\
\hline $\begin{array}{l}19 / 139^{v}-143^{r} / \\
121^{r}-124^{r}\end{array}$ & Georgius Florius & $\begin{array}{l}\text { Missa s. Come la } \\
\text { turturelle }\end{array}$ & $\begin{array}{l}5 \\
\text { A, Q. v.: není podložen text } \\
\text { A: Ao. 1600. } 21 . \text { Martii } \\
\text { Q. v.: Missa à } 5 \text { facta ad } \\
\text { imitationem Moduli Gallici Come la } \\
\text { turturelle. Cantus 2. Georgii Florii } \\
\text { Q. v.: Finis. Ao 1600. } 26 \text { Martii } \\
\end{array}$ \\
\hline $\begin{array}{l}20 / 143^{v}-145^{r} / \\
124^{v}-126^{v}\end{array}$ & Johannes Nucius & $\begin{array}{l}\text { Missa s. Chara } \\
\text { Theodoram }\end{array}$ & $5 / \mathrm{Ky}-\mathrm{Gl}$ \\
\hline $\begin{array}{l}21 / 145^{r}-147^{v} / \\
126^{v}-128^{v}\end{array}$ & \begin{tabular}{|l} 
Georgius \\
Cropatius
\end{tabular} & Missa & $\begin{array}{l}\text { 5/ bez } \mathrm{Cr} \\
\text { Q. v.: AD Sex vocum }\end{array}$ \\
\hline
\end{tabular}




\section{Benátský tisk mší Jiř́ho Cropatia}

Vzhledem k tomu, že se Cropatiův benátský tisk do dnešní doby nedochoval, musíme při úvahách o jeho vzniku, podobě a obsahu stejně jako o celé Cropatiově skladatelské činnosti formulovat pouze hypotézy. Název nejspíše zněl: Missarum tomus primus quinque vocum iuxta dodecachordi modos, dorii scilicet, hypodorii et lydii accurate compositus, recensque in luce editus (První díl mší pro pět hlasů v modech podle dvanáctistrunu, v dórském totiž, hypodórském a lydickém pečlivě složený a nedávno vydaný na světlo). Můžeme z toho vyvodit, že představoval první část pětihlasých zhudebnění mešního ordinaria podle tzv. dvanáctistrunu, tedy klasifikace dvanácti modů, které nově definoval Heinrich Glareanus ve třetím díle své práce Dodecachordon $(\Delta \Omega \Delta \mathrm{EKAXOP} \Delta \mathrm{ON})$, otištěné v roce 1547 . Cropatiův tisk obsahoval mši v dórském, hypodórském a lydickém modu. Netušíme, jestli měl Cropatius složené i mše v dalších modech, ${ }^{59}$ či je pouze zamýšlel zkomponovat. Nicméně i z konceptu Cropatiova benátského tisku musíme ocenit naznačovanou modernost jeho uvažování. Glareanovo pojetí dvanácti modů se v Evropě druhé poloviny 16. století teprve prosazovalo a z osmdesátých let nemáme z českých zemí žádný náznak jejího teoretického akceptování či praktického užívání. ${ }^{60}$ Cropatiovo „nové“, na humanistickém pojetí založené modální myšlení je ojedinělé i ve srovnání s největšími skladatelskými autoritami osmdesátých let 16. století, tedy s Orlandem di Lasso a Palestrinou. Oba dva totiž stále užívali tradiční systém osmi modů. Také v prostředí italské hudební kultury, kde Glareanův koncept převzal a rozpracoval především Giuseppe Zarlino, ${ }^{61}$ došlo k prosazování nového modálního systému jen postupně, a to i díky skladatelům, jako byli kupř. Claudio Merulo, Annibale Padovano, Giovanni a především Andrea Gabrieli. ${ }^{62} \mathrm{Za}$ zmínku samozřejmě stojí též sbírka v Čechách

59) Tedy frygickém, hypofrygickém, hypolydickém, mixolydickém, hypomixolydickém, aiolském, hypoaiolském, ionském a hypoionském.

60) FULLER, Sarah: Defending the Dodecachordon: Ideological Currents in Glarean's Modal Theory, in: Musical Theory in the Renaissance, ed. Cristle Collins Judd, Routledge, London - New York 2013 (dále COLLINS JUDD), s. 321-354. Výskyt tisku Glareanova Dodecachordonu máme v Čechách až z počátku 17. století, kdy ho měl ve své knihovně Jiř́ Bartholdus Pontanus z Breitenberka. Dochovaný exemplář však naznačuje, že nebyl v praxi užíván. Neobsahuje žádné připisy a je až „vzorně“ nedotčen. Srov. Knihovna Metropolitní kapituly v Praze, sign. Db a 30. Srov. také DANĚK, Petr: Historické tisky vokální polyfonie, rané monodie, hudební teorie a instrumentální hudby v českých zemích do roku 1630, KLP, Praha 2015, s. 84-85 (dále DANĚK).

61) Le Istitutioni armoniche, 1558/1573 a Dimostrationi armoniche, 1571. Da COL, Paolo: The Tradition and Science: The Institutioni harmoniche of Gioseffo Zarlino. Introduction to the Facsimile Edition, Bibliotheca Musica Bononensis II, in: COLLINS JUDD, op. cit. v pozn. 60, s. 373-393. Exemplář prvého tisku se nachází v pražské Kapucínské provinční knihovně, sign. 2C 31 (1). Je však velmi pravděpodobné, že se do Čech dostal až po roce 1600. Původním majitelem byl italský skladatel a básník, který na počátku 17. století až do své dramatické smrti působil v Praze, Giovanni Battista Massarengo, více HRADILOVÁ, Marta: Italština v knihovně kapucínského konventu na Hradčanech, in: Libri magistri muti sunt. Pocta Jaroslavě Kašparové, eds. Alena Císařová Smítková - Andrea Jelínková - Milada Svobodová, Knihovna Akademie věd ČR, Praha 2013, s. 335-346; nověji HRADILOVÁ, Marta: Giovanni Battista Massarengo and his Prague Library, La Bibliofilía. Rivista di Storia del Libro e di Bibliografia, roč. 120, č. 2, 2018, s. 201-208; DANĚK, op. cit. v pozn. 60, s. 91.

62) Srov. kupř. tisk Madrigali et Ricercari di Andrea Gabrieli a quattro voci, Venezia: Angelo Gardano 1589. RISM A/I G 77. 
působícího Alexandra Utendala Septem Psalmi penitentiales, již z roku 1570, ${ }^{63}$ kterou mohl Cropatius znát. V souvislosti s benátským vydáním Cropatiových mší je však třeba být v úvahách zcela realistickými. Gardano vytiskl Cropatiovy mše nikoliv proto, že by to byl tak výjimečný skladatel, jehož „sláva“ by došla až do Benátek, ale bezpochyby z toho důvodu, že za ním autor přišel a vytištění si zaplatil. Lze proto předpokládat, že náklad nebyl vysoký, byl pořízen střídmě a ani po jeho vzniku nenásledovala nějaká promyšlená distribuce po Itálii či Evropě. To vysvětluje i jeho dnešní absenci mezi dochovanými evropskými soubory hudebních tisků 16. století. Hlavním distributorem byl nejspíše autor sám. Nicméně o Cropatiově původní skladatelské činnosti pochybovat nelze. Svědčí o ní nejen zmínky o gardanovském tisku, opis mše ve vratislavském rukopisu, ale i svědectví spolucestovatelů do Svaté země, rozhodnutí zůstat a komponovat v klášteře sv. Salvátora v Jeruzalémě a také dárek Jiřímu Mehlovi v podobě pětihlasého mešního officia. Kde se umění komponovat naučil, je samozřejmě také nejasné. Bylo to nejspíše v souvislosti s jeho zahraničními studii, protože kdyby následoval cestu domácích českých skladatelů z prostředí literátských bratrstev a partikulárních škol, tak bychom jistě našli jeho skladby v dochovaném repertoáru z majetku českých literátů. Cropatius jako skladatel se však českému měštanskému prostředí několikerým způsobem vymykal, jak jsme již naznačili v předchozích částech tohoto textu.

\section{Cropatiův tisk v produkci Gardanovy tiskárny v roce $1578^{64}$}

Uvažujeme-li produkci Gardanovy tiskárny v roce vydání Cropatiova tisku a pokusíme-li se o určité zobecnění a srovnání, pak zjistíme, že v tomto roce Angelo Gardano vytiskl dvacet tři hudebních tisků. Většina z nich byla v kvartovém formátu, a tudíž se jednalo o hlasové sešity. Pouze titul Missarum liber primus Constanza Porty (1529-1601) ${ }^{65}$ byl realizován ve foliovém formátu, nákladným způsobem a je do něho zahrnuto sedm čtyřhlasých mší (Missa primi toni, Missa secundi toni, Missa tertii toni, Missa quarti toni, Missa quinti toni, Missa sexti toni, Missa de beata virgine), dvě pětitihlasé (Missa Descendit angelus, Missa Mortuorum) a tři šestihlasé (Missa Quemadmodum, Missa Audi filia, Missa La, sol, fa, re, $m i)$, otištěných na sto třiceti stranách ve stylu tzv. Chorbuchu.

Cropatiův tisk však byl ve všech ohledech skromnější. Obsahoval pouze tři mše, a tak je srovnatelný kupříkladu s jiným gardanovským tiskem mší ze stejného roku, a to s Liber primum missarum Constanza Antegnatiho (1549-1624) pro šest a osm hlasů. ${ }^{66}$ I v tomto tisku, stejně jako u Cropatia, byla zařazena pouze tři zhudebnění mešního ordinaria (Missa A l'aqua sagra, Anchor ch'io possa dire, Nasce la pena mia), takže jednotlivé hlasové sešity

63) UTENDAL, Alexander: Septem Psalmi penitentiales, adiunctis ex prophetarum scriptis orationibus eiusdem argumenti quinqué, ad Dodecachordi modos duodecim, Noribergae: Theodor Gerlach 1570. RISM U 119; BOSSUYT, Ignace: Die „Psalmi Poenitentiales" (1570) des Alexander Utendal. Ein künstlerisches Gegenstück der Bußpsalmen von 0 . Lassus und eine praktische Anwendung von Glareans Theorie der zwölf Modi, Archiv für Musikwissenschaft, roč. 38, 1981, č. 4, s. 279-295; POWERS, Harold: Is mode real? Pietro Aron, the octenary system, and polyphony, in: COLLINS JUDD, op. cit. v pozn. 60, s. 169-212, zvláště s. 171.

64) Zpracováno podle AGEE, op. cit. v pozn. 40, zvl. s. 219-223 a RISM Online.

65) RISM A/I P 5180.

66) RISM A/I A 1260. 
měly pouhých 17 stran kvartového formátu pro samostatný hlas a 22 stran pro sešit, který obsahoval dva hlasy (kupřr secundus chorus altus, secundus chorus tenor).

Gardanova tiskařská produkce z roku 1578 nabízela téměř všechny dobové druhy a žánry: nejpočetněji moteta (7), poté madrigaly (6), mše (4), nešporní žalmy (3), ricercari (1), canzoni spirituali (1) a sbírku jedinečných vokálně-instrumentálních tanečních skladeb Giorgia Maineria (ca. 1530/1540-1582) Il primo libro de balli a quattro voci. ${ }^{67}$ Je pozoruhodné, že až na jedinou výjimku, kterou je kolektivní sbírka Madrigali ariosi a quatro voci, composti da diversi eccellentissimi autori. Libro primo, ${ }^{68}$ vydával Gardano v tomto roce jen autorské tisky. ${ }^{69}$ Převažují mezi nimi samozřejmě Italové. Výjimku tvoří vedle Jiř́ího Cropatia i původem španělští skladatelé Don Ferdinando de las Infantas či Pietro/Pedro Valenzola. ${ }^{70}$ Svého druhu bohemikální či středoevropské souvislosti má tisk madrigalů Philippa de Monte Il settimo libro delli madrigali a cinque voci, ${ }^{71}$ protože je dedikován císaři Rudolfovi II. a předmluva je datována v únoru 1578 ve Vídni. ${ }^{72}$ Gardano však tiskl Monteho pravidelně a většinu jeho tisků vydával i opakovaně. ${ }^{73}$

\begin{tabular}{|l|l|l|l|}
\hline $\begin{array}{l}\text { Jméno autora (řazeno } \\
\text { abecedně) }\end{array}$ & $\begin{array}{l}\text { Zkrácený název / obsah tisku } \\
\text { RISM }\end{array}$ & $\begin{array}{l}\text { Počet } \\
\text { hlasů }\end{array}$ & Formát \\
\hline více autorů & $\begin{array}{l}\text { Madrigali ariosi a quatro voci, composti da diversi } \\
\text { eccellentissimi authori, novamente con somma diligentia } \\
\text { ristampati } \\
\text { RISM 157820 }\end{array}$ & 4 & $4^{\circ}$ \\
\hline $\begin{array}{l}\text { Antegnati, Constanzo } \\
\text { (1549-1624) }\end{array}$ & $\begin{array}{l}\text { Liber primus missarum sex et octo vocum } \\
\text { RISM A/I A 1260 }\end{array}$ & 6,8 & $4^{\circ}$ \\
\hline $\begin{array}{l}\text { Asola, } \\
\text { Giovanni Matteo } \\
\text { (ca. 1532-1609) }\end{array}$ & $\begin{array}{l}\text { Vespertina omnium solemnitatum psalmodia, iuxta } \\
\text { decretum sacrosancti Tridentini concilii, duoque; } \text { B. Virginis } \\
\text { cantica primi toni, cum quatuor vocibus ... primus chorus } \\
\text { extat etiam secundus chorus, ad pares voces concinendus } \\
\text { RISM A/I A 2532 }\end{array}$ & 4 & $4^{\circ}$ \\
\hline
\end{tabular}

67) RISM A/I M 187.

68) RISM 157820; pozoruhodné je, že tento tisk se dochoval pouze v Polsku, Wroclaw, Biblioteka Cyfrowa Uniwersytetu Wroctawskiego, RISM Recueils Imprimés XVIe - XVII siècles, s. 306. Exemplář však pochází z Legnice, z knihovny knížete Jiřího Rudolfa, srov. KOLBUSZEWSKA, Aniela: Katalog zbiorów muzycznych legnickiej biblioteki księcia Jerzego Rudolfa „BIBLIOTHECA RUDOLPHINA“, Legnickie Towarzystwo Muzyczne, Legnica 1992, s. 24. Tisk je součástí pozoruhodného konvolutu, kde nalezneme i řadu dalších italských tisků, včetně tří gardanovských z roku 1578 (Filippo Nicoletti, Pietro Valenzola, Madrigali ariosi). Dostupné z: https://bibliotekacyfrowa.pl/dlibra/publication/63908/edition/63824?language=en [cit. 6. 4. 2020].

69) Svého druhu kolektivní tisk je i ojediněle dochovaný Motectorum liber secundus, RISM $1578^{2}$, RISM A/I L 2806, nebot' obsahuje skladby dvou autorů.

70) RISM A/I V 144, tento relativně četně dochovaný tisk se vyskytuje i ve třech exempláŕích v Polsku. http:// www.rism.info/index.php?id=31\&L=0

71) RISM A/I M 3366.

72) Van DOORSLAER, Georg: La vie et les oevres de Philippe de Monte 1521-1603, Georg Olms Verlag, Bruxelles 1921, s. 115-116.

73) Tamtéž, kupř. s. 116. 


\begin{tabular}{|c|c|c|c|}
\hline $\begin{array}{l}\text { Jméno autora (řazeno } \\
\text { abecedně) }\end{array}$ & $\begin{array}{l}\text { Zkrácený název / obsah tisku } \\
\text { RISM }\end{array}$ & $\begin{array}{l}\text { Počet } \\
\text { hlasů }\end{array}$ & Formát \\
\hline $\begin{array}{l}\text { Asola, } \\
\text { Giovanni Matteo }\end{array}$ & $\begin{array}{l}\text { Secundus chorus vespertinae omnium solemnitatum } \\
\text { psalmodiae, iuxta sacrosancti Tridentini concilii decretum, } \\
\text { duoque B. Virginis cantica, primi toni, vocibus quatuor } \\
\text { paribus concinendus } \\
\text { RISM A/I A } 2538\end{array}$ & 4 & $4^{\circ}$ \\
\hline $\begin{array}{l}\text { Balbi, Lodovico } \\
\text { (1545-1604) }\end{array}$ & $\begin{array}{l}\text { Ecclesiasticarum cantionum quatuor vocum omnibus } \\
\text { Adventus dominicis, nec non Septuagesimae, Sexagesimae, } \\
\text { Quinquagesimae, simul atque quibuscunque totius anni } \\
\text { opportunitatibus deservientium } \\
\text { RISM A/I B } 737\end{array}$ & 4 & $4^{\circ}$ \\
\hline $\begin{array}{l}\text { Infantas, } \\
\text { Don Ferdinando de las } \\
(1534-\text { ca. 1610) }\end{array}$ & $\begin{array}{l}\text { Sacrarum varii styli cantionum tituli Spiritus sancti, liber } \\
\text { primus cum quatuor vocibus } \\
\text { RISM A/I I } 37\end{array}$ & 4 & $4^{\circ}$ \\
\hline $\begin{array}{l}\text { Ingegnieri, } \\
\text { Marc'Antonio } \\
\text { (ca. 1535-1592) }\end{array}$ & $\begin{array}{l}\text { Il primo libro de madrigali a quatro voci, novamente con ogni } \\
\text { dilligentia ristampati } \\
\text { RISM A/I I } 51\end{array}$ & 4 & $4^{\circ}$ \\
\hline $\begin{array}{l}\text { Cropatius, Georgius } \\
\text { (ca. 1550-?) }\end{array}$ & Georg Cropatii missarum tomus primus & 5 & $4^{\circ}$ \\
\hline $\begin{array}{l}\text { Lasso, Orlando di } \\
(1532-1594)\end{array}$ & $\begin{array}{l}\text { Sacrae cantiones (vulgo motecta appellatae) quinque, et } \\
\text { sex vocum, tum viva voce tum omnis generis instrumentis } \\
\text { cantatu commodissimae, liber tertius } \\
\text { RISM A/I L 910 }\end{array}$ & $\begin{array}{l}5,6 \mathrm{a} \\
\text { více }\end{array}$ & $4^{\circ}$ \\
\hline Lasso, Orlando di & $\begin{array}{l}\text { Liber septimus ... sacrorum cantuum quinis vocibus } \\
\text { concinendorum, quinq: instrumentorum sonis, et vocum } \\
\text { concentibus adaptari possunt } \\
\text { RISM A/I L 911 }\end{array}$ & 5 & $4^{\circ}$ \\
\hline $\begin{array}{l}\text { Lombardi, Bartolomeo } \\
\text { (?-?) }\end{array}$ & $\begin{array}{l}\text { Mottectorum liber secundus cum quinque vocibus } \\
\text { RISM A/I L } 2806\end{array}$ & 5 & $4^{\circ}$ \\
\hline $\begin{array}{l}\text { Luzzaschi, Luzzasco } \\
\text { (ca. 1545-1607) }\end{array}$ & $\begin{array}{l}\text { Il Secondo. Libro. De. Ricercari. | a Quattro voci, DI Luzzasco } \\
\text { Luzzaschi | Ferrarese partit. | } 1578 \\
\text { Dochováno pouze v rukopise }{ }^{74}\end{array}$ & 4 & $4^{\circ}$ \\
\hline $\begin{array}{l}\text { Mainerio, Giorgio } \\
\text { (ca. 1535-1582) }\end{array}$ & $\begin{array}{l}\text { Il primo libro de balli a quattro voci accommodati per cantar } \\
\text { et sonar d'ogni sorte de istromenti } \\
\text { RISM A/I M } 187\end{array}$ & 4 & $4^{\circ}$ \\
\hline $\begin{array}{l}\text { Massaini, Tiburtio } \\
\text { (ca. 1550-ca. 1609) }\end{array}$ & $\begin{array}{l}\text { Missae quinque et sex vocum ... Missa Rorate coeli, quinque } \\
\text { voc.; Missa Nuncium vobis, quinque voc.; Missa Omnes } \\
\text { gentes, sex voc.; liber primus } \\
\text { RISM A/I M } 1269\end{array}$ & 5,6 & $4^{\circ}$ \\
\hline
\end{tabular}

74) Dochováno v dobovém opise, Bologna, Convento di S. Francesco, Biblioteca Martini; LADEWIG, James: The Use of Opens Score as a Solo Keyboard Notation in Italy ca. 1530-1740, in: Essays in Honor of John F. Ohl: A Compendium of American Musicology, Northwestern University Press, Evaston, Illinois 2001, s. 78, 84. RISM ID no.: 859000063. 


\begin{tabular}{|c|c|c|c|}
\hline $\begin{array}{l}\text { Jméno autora (řazeno } \\
\text { abecedně) }\end{array}$ & $\begin{array}{l}\text { Zkrácený název / obsah tisku } \\
\text { RISM }\end{array}$ & \begin{tabular}{|l|} 
Počet \\
hlasů \\
\end{tabular} & Formát \\
\hline $\begin{array}{l}\text { Merulo, Claudio } \\
\text { (1533-1604) }\end{array}$ & $\begin{array}{l}\text { Liber primus sacrarum cantionum quinque vocibus } \\
\text { RISM A/I M } 2358\end{array}$ & 5 & $4^{\circ}$ \\
\hline Merulo, Claudio & $\begin{array}{l}\text { Liber secundus sacrarum cantionum, quinque vocibus } \\
\text { RISM A/I M } 2359\end{array}$ & 5 & $4^{\circ}$ \\
\hline $\begin{array}{l}\text { Monte, Philippe de } \\
\text { (1521-1603) }\end{array}$ & $\begin{array}{l}\text { Il settimo libro delli madrigali a cinque voci } \\
\text { RISM A/I M } 3366\end{array}$ & 5 & $4^{\circ}$ \\
\hline $\begin{array}{l}\text { Nicoletti, Filippo } \\
\text { (ca. 1555-ca. 1620) }\end{array}$ & $\begin{array}{l}\text { Il primo libro de madrigali ... a cinque voci } \\
\text { RISM A/I N } 676\end{array}$ & 5 & $4^{\circ}$ \\
\hline $\begin{array}{l}\text { Pelio, Giovanni } \\
\text { (?-?) }\end{array}$ & $\begin{array}{l}\text { Il primo libro delle canzoni spirituali a cinque voci } \\
\text { RISM A/I P } 1147\end{array}$ & 5 & $4^{\circ}$ \\
\hline $\begin{array}{l}\text { Pordenone, } \\
\text { Marc'Antonio } \\
\text { (ca. 1535-ca. 1590) }\end{array}$ & $\begin{array}{l}\text { Il quinto libro de madrigali a cinque voci } \\
\text { RISM A/I P } 5105\end{array}$ & 5 & $4^{\circ}$ \\
\hline $\begin{array}{l}\text { Porta, Constanzo } \\
\text { (ca. 1528-1601) }\end{array}$ & $\begin{array}{l}\text { Missarum liber primus } \\
\text { RISM A/I P } 5180\end{array}$ & $4,5,6$ & Folio \\
\hline $\begin{array}{l}\text { Rossi, Flaviano } \\
\text { (?-?) }\end{array}$ & $\begin{array}{l}\text { Psalmorum vesperarum omnium totius anni dierum festorum } \\
\text {... lib. primus ... quatuor vocum } \\
\text { RISM A/I R } 2737\end{array}$ & 4 & $4^{\circ}$ \\
\hline $\begin{array}{l}\text { Valenzola, Pietro/ } \\
\text { Pedro } \\
\text { (?-?) }\end{array}$ & $\begin{array}{l}\text { Madrigali ... a cinque voci, con uno a sei, et uno dialogo } \\
\text { a otto ... libro primo } \\
\text { RISM A/I V } 144\end{array}$ & $5,7,8$ & $4^{\circ}$ \\
\hline
\end{tabular}

Tiskařská produkce Angela Gardana v roce 1578 je co do množství, počtu a profilu skladatelů a obsahu srovnatelná s produkcí jiné významné benátské tiskárny rodiny Scottů, která však vydávala nejen hudební tisky, ale i knihy z oblasti medicíny, filozofie či teologie. ${ }^{75}$ Po smrti výrazné tiskařské osobnosti Girolama Scotta v roce 1572 provozoval tiskárnu jeho synovec Melchiorre Scotto, ale stále na titulních stránkách uváděl jméno svého významnějšího strýce (herede di G. Scotto). Tato tiskárna vydala v roce 1578 dvě desítky tisků s díly vokální polyfonie, přičemž žánrová skladba vydaných děl je obdobná jako u Angela Gardana. Ve výběru autorů se samozřejmě tiskárny liší, nicméně profilově si jsou podobné. Některé autory (Philippe de Monte, Infantas, Massaini) vydávají shodně. Scotto však v tomto roce preferuje více tisků obsahujících skladby několika autorů a ve srovnání s Gardanem netiskne vůbec mše. ${ }^{76}$ Je proto pochopitelné, proč si Jiří Cropatius vybral k realizaci svého tisku mší právě tiskárnu Angela Gardana.

\section{Závěr}

Ačkoli Jiří Cropatius byl dosud spíše jen jménem v encyklopediích a hudebních slovnících, lepší dostupnost starší literatury i pramenů a také jejich moderní zpracování dnes umožnily doplnit mozaiku jeho života o nové a zajímavé skutečnosti. Z neznámého protestanta z Teplic se po doplnění nových poznatků stal cestovatel a konvertita, z básníka s vitenberským

75) BERNSTEIN, Jane A.: Music Printing in Renaissance Venice: the Scotto Press, 1539-1572, Oxford University Press, 1998.

76) Srov. RISM Online, Scotto 1578. 
školením se stal uznávaný hudebník a znalec jazyků, který se přátelil s alexandrijským patriarchou a svými texty oslavoval Giuseppe Zarlina. I nadále můžeme Jiř́ho Cropatia vnímat jako autora mší, z nichž jedna se zčásti dochovala v Berlíně a je v tomto článku poprvé uvedena do širších souvislostí. Do budoucna nezbývá než doufat, že se postupem času dozvíme ještě další detaily z jeho života a hlavně, že se snad podaří nalézt Cropatiův benátský tisk. I když je hudba Jiř́iho Cropatia doložena jen ilustrativním zlomkem, a tudíž o ní dnes nelze vynést žádný rozumný soud, je evidentní, že patřila stejně jako její autor k dobové hudební kultuře. Z dosavadní muzikologické literatury jsme navyklí uvažovat v podstatě o dvojím typu skladatelů vokální polyfonie, kteří se podíleli na utváření předbělohorské či rudolfínské etapy hudební kultury v Čechách: o autorech pocházejících z prostředí literátských bratrstev a o skladatelích cizího původu, kteří přišli do Čech v naprosté většině v souvislosti s habsburským dvorem, at již v období působení místodržitele Ferdinanda Tyrolského či během pražského pobytu císaře Rudolfa II. První typ skladatelů se hudbě učil především praxí v době školních studií, která pokračovala celoživotním zpěvem v kostele. Ke svému kompozičnímu stylu se tito autoři dostávali zejména poznáváním skladeb respektovaných autorů prostřednictvím importovaných tisků (Jacobus Clemens non Papa, Nicolas Gombert) a nápodobou uznávaných skladatelů domácích. Dvorští skladatelé a komponující hudebníci byli na vyšším stupni skladatelské zručnosti, protože dobu svého školení a seznamování s hudbou většinou strávili v př́mém kontaktu s výjimečnými skladateli své doby (Orlando di Lasso, Philippe de Monte), kteří je vychovávali systematicky. Inspirace pak tito dvorští umělci získávali i během cest po Evropě, při kterých hrála s postupujícím šestnáctým stoletím italská hudební kultura stále významnější roli. Do těchto dvou kategorií se nám doposud složitě zařazovali dva skladatelé, kteří působili v Čechách: Jacobus Handl Gallus a Kryštof Harant. Nyní k nim přibyl i Jiří Cropatius. Jedním ze závěrů našeho textu tedy může být i poznání, že těchto solitérů, kteří nepatřili k žádné ze dvou zmíněných velkých skupin, bude nejspíše více. Podle našich zjištění je třeba je hledat především v prostředí šlechtických dvorů a sídel a v souvislosti $\mathrm{s}$ činností klášterů a církevních řádů.

Adresa: Marta Vaculínová, Kabinet pro klasická studia Filozofického ústavu AV ČR, Na Florenci 1420/3, 11000 Praha 1, Česká republika

E-mail:vaculinova@ics.cas.cz

Adresa: Petr Daněk, Ústav dějin umění AV ČR, Husova 4, 11000 Praha 1, Česká republika E-mail:danek@udu.cas.cz 